\title{
History and Structure of Article III
}

\section{Citation}

Daniel J. Meltzer, History and Structure of Article III, 138 U. Pa. L. Rev. 1569 (1990).

\section{Published Version}

http://scholarship.law.upenn.edu/penn_law_review/vol138/iss6/2/

\section{Permanent link}

http://nrs.harvard.edu/urn-3:HUL.InstRepos:12965068

\section{Terms of Use}

This article was downloaded from Harvard University's DASH repository, and is made available under the terms and conditions applicable to Other Posted Material, as set forth at http:// nrs.harvard.edu/urn-3:HUL.InstRepos:dash.current.terms-of-use\#LAA

\section{Share Your Story}

The Harvard community has made this article openly available.

Please share how this access benefits you. Submit a story.

\section{Accessibility}




\title{
THE HISTORY AND STRUCTURE OF ARTICLE III
}

\author{
Daniel J. Meltzer $†$
}

In his present article and two that preceded it, ${ }^{1}$ Akhil Amar takes issue with what has come to be regarded as the traditional view of article III-that Congress has plenary authority over federal court jurisdiction. According to that view, Congress may deprive the lower federal courts, the Supreme Court, or all federal courts of jurisdiction over any cases within the federal judicial power, excepting only those few that fall within the Supreme Court's original jurisdiction. ${ }^{2}$

Amar's powerful challenge to this tradition resembles two other

$\dagger$ Professor of Law, Harvard University. A.B. 1972, J.D. 1975, Harvard University. I am grateful to Dick Fallon, Willy Fletcher, Gerry Gunther, and David Shapiro for their encouragement and perceptive comments, and to Matt Kreeger and Sylvia Quast for helpful suggestions and tireless research assistance. Special thanks go to Akhil Amar, whose careful and probing criticism saved me from errors and clarified my own thinking, even though he did not quite convert me.

1 See Amar, Marbury, Section 13, and the Original Jurisdiction of the Supreme Court, 56 U. CHI. L. Rev. 443 (1989) [hereinafter Amar, Original Jurisdiction]; Amar, $A$ NeoFederalist View of Article III: Separating the Two Tiers of Federal Jurisdiction, 65 B.U.L. REv. 205 (1985) [hereinafter Amar, Neo-Federalist View].

2 See, e.g., Bator, Congressional Power Over the Jurisdiction of the Federal Courts, 27 Vill. L. Rev. 1030, 1030-31 (1982); Gunther, Congressional Power to Curtail Federal Court Jurisdiction: An Opinionated Guide to the Ongoing Debate, 36 STAN. L. REv. 895, 90110 (1984); Redish, Congressional Power to Regulate Supreme Court Appellate Jurisdiction Under the Exceptions Clause: An Internal and External Examination, 27 Vill. L. REv. 900, 902 (1982) [hereinafter Redish, Power to Regulate]; Wechsler, The Courts and the Constitution, 65 Colum. L. Rev. 1001,1005 (1965). When discussing constitutional limits on congressional power, like Amar, I put to one side "external" limits based on constitutional provisions other than article III.

Professor Gunther, who wrote before Amar first addressed this topic, has since indicated that although he finds Amar's thesis powerful, and though Amar has forced Gunther to rethink his position and has persuaded him that there is a stronger case to be made for article III limits on congressional control, see G. Gunther, Remarks at Bicentennial Conference of First Judiciary Act (Sept. 21, 1989) (on file with the University of Pennsyluania Law Review), on balance Gunther still inclines towards the traditional view, see Letter from Gerald Gunther to Daniel J. Meltzer (Feb. 26, 1990) (on file with the University of Pennsylvania Law Review).

Amar occasionally treats Henry Hart as a traditionalist, and sometimes associates him with the views of the third edition of the Hart and Wechsler casebook, P. BATOR, D. Meltzer, P. Mishkin \& D. Shapiro, Hart \& Wechsler's The Federal Courts aNd the Federal System (3d ed. 1988) [hereinafter Hart \& Wechsler]. Hart suggested, however, that article III limits Congress's power to restrict the Supreme Court's jurisdiction. See Hart, The Power of Congress to Limit the Jurisdiction of Federal Courts: An Exercise in Dialectic, 66 HARv. L. REv. 1362, 1364-65 (1953); see also infra note 144. The third edition neither endorses nor rejects Hart's views. 
recent arguments for limitations on congressional power under article III. In 1981, Lawrence Sager contended that some federal court, Supreme or inferior, must have jurisdiction to review "state court decisions that repudiate federal constitutional claims of right."3 Sager rested in part on the importance of the tenure and salary protection that article III affords to all federal judges. Three years later, Robert Clinton argued that article III requires that some federal court have jurisdiction over all cases within the federal judicial power. ${ }^{4}$

In both of these accourits, the scope of mandatory jurisdiction is problematic. Sager's focus on constitutional claims relating to federal supremacy is somewhat unpersuasive when one recalls that the Constitution itself imposes few restraints on the states, and that delegates to the Constitutional Convention and the state ratifying conventions viewed federal jurisdiction as most vital in actions under federal treaties and national revenue laws or in admiralty. ${ }^{5}$ Clinton's virtually unlimited obligation is hard to square with the First Judiciary Act and subsequent congressional legislation. ${ }^{6}$ Moreover, his

3 Sager, Foreword: Constitutional Limitations on Congress' Authority to Regulate the Jurisdiction of the Federal Courts, 95 FlaRv. L. REv. 17, 44 (1981).

4 See Clinton, A Mandatory View of Federal Court Jurisdiction: A Guided Quest for the Original Understanding of Article III, 132 U. PA. L. REv. 741, 753, 793-94 (1984) [hereinafter Clinton, $A$ Guided Quest]. Clinton added a qualification: Congress may "limit the mode of review (i.e., review of facts) or . . . prevent misuse of federal judicial resources by limiting trivial, insignificant, or vexatious appeals." Id. at 839-40.

5 See, e.g., 3 The Debates in the Several. State Conventions on the Adoption of the Federal Constitution 532 (J. Elliot ed. 1901) [hereinafter Elliot's Debates] (remarks of James Madison); $4 \mathrm{id}$. at 160, 164 (remarks of William Maclaine); infra text accompanying notes 30-52; see also $3 \mathrm{~J}$. STORY, CoMmentaRIES ON THE Constitution of THE UNITEd STATES $\$ 1637$, at 505 (1833) (stressing special importance of jurisdiction over cases arising under treaties); Redish, Constitutional Limitations on Congressional Power to Control Federal Jurisdiction: A Reaction to Professor Sager, 77 Nw. U.L. REv. 143, 152 (1982) [hereinafter Redish, Constitutional Limitations] (noting that the salary and tenure protection on which Sager relies applies to all of the federal judicial power, not just to constitutional cases).

6 See Amar, The Two-Tiered Struture of the Judiciary Act of 1789, 138 U. PA. L. REv. $1499,1519-20$ (1990). In a subsequent article, Clinton struggles to establish that the First Judiciary Act was largely consistent with his interpretation. See Clinton, $A$ Mandatory View of Federal Court Jurisdiction: Early Implementation of and Departures from the Constitutional Plan, 86 Colum. L. Rev. 1515 (1986) [hereinafter Clinton, Early Implementation]. But in addition to its jurisdictional amount limitations, see Amar, supra, at 1519-21, the Act did not fully vest the federal judicial power in other important respects:

1. State courts had concurrent jurisdiction over suits by the United States and suits between a state and a non-citizen. There was no express provision for removal or Supreme Court review. See also infra note 124 (discussing possibility that Supreme Court had implicit power to remove).

2. Diversity jurisdiction was limited by the assignee clause, and more significantly 
prescription in diversity cases is quite awkward: either Congress must give lower federal courts exclusive jurisdiction (or give every party in every diversity case a right to invoke federal jurisdiction), ${ }^{7}$ despite widespread concerns in the ratification debates about any exercise of federal diversity jurisdiction, ${ }^{8}$ or the Supreme Court must review state court decisions on matters of non-federal law.

Amar occupies a middle ground between Sager and Clinton. He argues that the federal judicial power "must, as an absolute minimum, comprehend the subject matter jurisdiction to decide finally all cases involving federal questions, admiralty, or public ambassadors," and "may-but need not-extend to cases in the six other, partydefined jurisdictional categories."9 Thus, Congress's obligation under article III to assign jurisdiction to either the Supreme Court or the lower federal courts reaches beyond constitutional claims to a

by the provision permitting removal only when the defendant was not a citizen of the forum state. Again, there was no Supreme Court review of state court decisions.

In addition, whether or not "the framers" gave any thought to the complete diversity rule of Strawbridge v. Curtiss, 7 U.S. (3 Cranch) 267 (1806), it is clear today that the statutory scope of diversity jurisdiction falls far short of its constitutional scope. Finally, Clinton's thesis, like Amar's, must account for the First Judiciary Act's failure fully to vest jurisdiction over federal question cases, cases affecting ambassadors and other foreign officials, and arguably cases in admiralty. See infra text accompanying notes 55-103.

7 I assume here, and throughout this Article, that a "mandatory" theory would permit a case to be actually litigated in state court without Supreme Court review, so long as all parties had the chance to invoke federal jurisdiction but instead chose state court adjudication. For a defense of that assumption in a slightly different context, see Meltzer, Legislative Courts, Legislative Power, and the Constitution, 76 IND. L.J. 291, 301-04 (1990).

8 See infra note 48 and accompanying text.

9 Amar, Neo-Federalist View, supra note 1, at 229. Amar's division into subjectmatter and party-based jurisdictions follows that of Chief Justice John Marshall. See, e.g., Cohens v. Virginia, 19 U.S. (6 Wheat.) 264, 378 (1821).

As Amar elaborates in his reply, his thesis would not permit Congress to abolish any of the nine jurisdictions in its entirety, but requires only that Congress must give the federal courts power to hear at least two controversies in each case. See Amar, Reports of My Death Are Greatly Exaggerated: A Reply, 138 U. PA. L. Rev. 1651, 1652 (990) [hereinafter Amar, Reply]; see also Amar, Neo-Federalist View, supra note 1, at 240 n.119 (stating that "arguably" federal courts must have that minuscule amount of party-based jurisdiction).

One of the so-called party-based jurisdictions-jurisdiction when citizens of the same state claim lands under grants of different states-is in fact based primarily upon subject matter (conflicting land grants); the limitation to parties of the same state is beside the point, since citizens of different states would in any event fall within the diversity jurisdiction. This jurisdiction does have a party-based flavorthe involvement (as grantors rather than litigants) of two different states. But the jurisdiction affecting ambassadors and other diplomats, which Amar treats as subjectmatter based, has just as much of a party-based flavor. In any event, for simplicity I shall follow Amar's terminology. 
"mandatory tier" (containing three heads of jurisdiction), but not to the entire federal judicial power.

Amar's account is not, however, simply a compromise position. It is rooted, first of all, in an interpretation of the Constitution's text. Article III provides that the judicial power "shall be vested" in the Supreme Court and such lower courts as Congress may create, and "shall extend" to nine categories of jurisdiction. In the description that follows of those nine categories, the word "all" modifies only the first three. ${ }^{10}$ Justice Story noted this textual variation in Martin $v$. Hunter's Lessee, ${ }^{11}$ but thereafter it was overlooked until revived by Amar. ${ }^{12}$

Amar's argument that article III requires the federal judiciary to exercise judicial power in "all" cases within the first three categories, while permitting it to do so in any cases within the remaining six, is not exclusively textual. His imaginative, multi-faceted, and forcefully presented position draws on a rich variety of supporting arguments.

Amar's present article focuses on the Judiciary Act of 1789, and responds in detail to a brief passage in Hart $\mathcal{E}^{\circ}$ Wechsler that raises the following questions about his thesis:

If the distinction between the two tiers was so significant, why is there so little evidence of explicit recognition of that distinction in contemporary commentary or in the available history of the 1789 Act? Why did that Act leave some significant gaps in federal court jurisdiction, even in the 'mandatory' categories? Why did the drafters of Article III single out cases affecting ambassadors, etc., for

10 In relevant part, article III provides:

The judicial Power shall extend to all Cases, in Law and Equity, arising under this Constitution, the Laws of the United States, and Treaties made, or which shall be made, under their Authority;-to all Cases affecting Ambassadors, other public Ministers and Consuls; - to all Cases of admiralty and maritime Jurisdiction;-to Controversies to which the United States shall be a Party;-to Controversies between two or more States;--between a State and Citizens of another State;--between Citizens of different States;--between Citizens of the same State claiming Lands under the Grants of different States, and between a State, or the Citizens thereof, and foreign States, Citizens or Subjects.

U.S. Const. art. III, $\S 2$.

1114 U.S. (1 Wheat.) 304 (18:16).

12 In 1981, Lawrence Sager did describe Martin as stating "that Congress is required to vest all article III jurisdiction (or at least jurisdiction over those cases that are within the scope of article III by' virtue of subject matter rather than the identity of the parties) in some federal court," but did not develop the qualification. See Sager, supra note 3, at 32 n.39; see also id. at 34 n.49.

Amar also suggests that the distinction is noted in other nineteenth century opinions. For discussion of this point, see infra note 228. 
mandatory treatment and leave Congress an option in cases in which the United States was a party ? $^{13}$

I will take up Amar's response in Part II. First, in Part I, I will discuss whether the Constitutional Convention and ratification debates support his distinction between mandatory and nonmandatory tiers in article III. Part III offers some more general comments about the significance of the historical record and the persuasiveness of his approach. Finally, in Part IV, I will consider the question: What turns on resolution of the debate about congressional power over federal court jurisdiction?

\section{The Constitutional Convention, the Ratification Debates, AND THE TWo-TIER THEsIS}

\section{A. The Textual Basis: Above All, of "All"}

Amar's argument begins with the constitutional text. One hesitates to add to the ink that has been spilled over the meaning of "shall" in article III. ${ }^{14}$ The distinctive question that Amar raises is

13 Hart \& Wechsler, supra note 2, at 386-87 (footnotes omitted). The casebook continues:

And what are the present-day implications of the thesis for the broad scope of the Supreme Court's discretion to deny certiorari? Or for the authority of Congress to delegate certain matters to the final decision of a non-Article III federal tribunal? Even the most ardent advocates of a constitutional right to judicial review have not claimed that any matter that can be considered a "case" within the scope of Article III is for that reason alone beyond the authority of Congress to delegate to an administrative agency for final decision.

Id. at 387 (footnote omitted).

14 Article III begins: "The judicial Power of the United States, shall be vested in one supreme Court, and in such inferior Courts as the Congress may from time to time ordain and establish" U.S. CoNST. art. III, \& 1 (emphasis added). For the use of the word "shall" in article III, $\S 2$, see supra note 10 .

Amar's view that "shall" is mandatory is set forth in Amar, Neo-Federalist View, supra note 1 , at $212,215,229-30,239-40$. It seems quite possible that "shall" is mandatory in a more limited sense: if the judicial power is exercised by the federal government, the exercise must be by article III courts. A somewhat different approach is to read the "shall extend" language as referring only to matters over which the federal courts have the capability (rather than an obligation) to hear, and "shall be vested in" as referring to the courts that may (rather than must) exercise that capability.

I have only one other observation to add. It was left to the Committee of Detail to prepare a draft fleshing out the Convention's decisions about the federal judiciary. The proposal approved by the Convention began this way: "Resolved That a national Judiciary be established to consist ...." 2 The Records OF The Federal. Convention of 1787, at 132 (M. Farrand ed. 1966) [hereinafter REcoRDs]; see also I id. at 21-22, 230-31. The familiar phrasing found in article III-"The judicial Power 
the relationship between that verb and the selective use of "all" in article III's nine categories of federal jurisdiction.

There is some force in Martin Redish's objection that article III's language is hardly the obvious way to express an intent that cases within Amar's first tier, but not those within the second, must be heard by some article III court. ${ }^{15}$ At the same time, far too many constitutional interpretations could be defeated by the claim that, with 20/20 hindsight, the framers could have expressed their support for a particular view more clearly. Amar puts his textual argument in its best light by asking whether it can be a mere coincidence that article III uses the word "all" selectively not only when initially listing the nine heads of jurisdiction, but also when describing the Supreme Court's original jurisdiction-where "all" modifies the subject-matter component (ambassadors) but not the party-based one (state as a party). ${ }^{16}$

of the United Sates, shall be vested in . .."-appears to have originated in the Wilson-Rutledge draft in the Comrnittee of Detail, see 2 Records, supra, at 172-73, and that language tracks the "shall be vested language" with which articles I and II each begins. See, e.g., Martin v. Hur.ter's Lessee, 14 U.S. (1 Wheat.) 304, 329 (1816) (noting this point). It seems plausible that the language was chosen as much for symmetry as to reflect a decision (hardly clear from the Convention's proposal) that some or all of the federal judicial power must be exercised by the federal judiciary.

The positions of the various branches are not, to be sure, entirely symmetrical: no other branch can determine whether Congress exercises its legislative powers under article I; to some extent, the same is true of executive powers under article II, but to a considerable extent the scope of executive power depends upon what legislation has been enacted. In theory, the judiciary could be situated like Congress (i.e., having power that no other branch can regulate) or like the executive (i.e., having some powers dependent upon congressional legislation). Indeed, in the debate on the First Judiciary Act, Representative Stone stated that just as the failure to enact a tax does not divest Congress of the legislative power, so the failure to give the federal courts jurisdiction does not divest them of the judicial power. See 1 Annals of Cong. 824 (J. Gales ed. 1789) (Note that there are two editions of the Annals of Congress and that this Article cites to a different edition than does Professor Amar's article). Of course, in that same debate, contrary views were also expressed. See infra notes 112-13 and accompanying text.

15 See M. Redish, Federal Courts: Cases, Comments and Questions 185 (2d ed. 1989). During debate on The First Judiciary Act, Representative Stone stated:

It is not said in that instrument that you shall exercise the judicial power over all those cases, but that the judicial power shall extend to those cases. If it had been the idea of the Convention that its judiciary should extend so as positively to have taken in all these cases, they would so have declared it, and been explicit; but they have given you a power to extend your jurisdiction to them, but have not compelled you to that extension. Annals of Cong., supra note 14, at 823.

16 See Amar, supra note 6, at 1524-25; see also Amar, Original Jurisdiction, supra note 1 , at 480 (noting the same). But see supra note 9 (questioning whether the jurisdiction affecting ambassadors is appropriately categorized as based on subject matter). 
There is, however, an alternative explanation for this textual variation. Each subject matter clause extends to "all cases," while each of the party-based clauses extends to "controversies." 17 Willy Fletcher recently pointed to considerable evidence that in the early years of the nation, Justices and commentators understood "cases" to encompass criminal and civil proceedings, while "controversies" were civil only. ${ }^{18}$ And during the ratification era, at least one reference, in the letters of the anti-federalist "Agrippa," appears to reflect that same understanding. ${ }^{19}$ Though use of the word "all" to modify "cases" would not be strictly necessary if the distinction between cases and controversies were generally understood, it remains possible that "all" was meant to reinforce the breadth of "cases" rather than to suggest that the subject matter clauses are mandatory. ${ }^{20}$

17 See supra note 10.

18 See Fletcher, Exchange on the Eleventh Amendment, 57 U. CHI. L. REv. 131, 133 (1990). Fletcher notes particularly the explanation of this distinction found in St. George Tucker's appendix to his 1803 American; edition of Blackstone. See 1 Blackstone's Commentaries: WITH Notes OF REFERENCE to tHe Constitution aNd LAwS OF THE FEDERAL Government OF the UNITED STATES AND OF THE Commonwealth of Virginia 420-21 (St. George Tucker ed. 1803); see also 1 W. Crosskey, Polmics aND tHe Constitution 614-15 (1953) (stating, without supporting citation, that the framers understood "controversies" as covering only civil actions); Casto, An Orthodox View of the Two-Tier Analysis of Congressional Control Over Federal Jurisdiction, 89, 90 \& n.4 (1990) (noting that some modern judges have set forth the same understanding, and citing Aetna Life Ins. Co. v. Haworth, 300 U.S. 227, 239 (1937)).

Story himself may have agreed with this interpretation. His Commentaries expressly state that the federal question and admiralty jurisdictions extend to criminal cases, see $3 \mathrm{~J}$. STORY, supra note 5, § 1634, at 502 \& n.2 (citing Tucker's explanation of the distinction); id. § 1667, at 534. When Story then turns to the first of the "controversy" jurisdictions (United States as a party), he cites at length Tucker's explanation of the distinction, though without clearly endorsing it. See id. $\S 1668$, at $536 \mathrm{n} .2$.

19 Agrippa argued:

In article III, section 2, it is declared, that 'the judicial power shall extend to all cases in law and equity arising under this constitution, the laws of the United States, and treaties made or which shall be made under their authority.' Among the cases arising under this new constitution are reckoned, 'all [sic] controversies between citizens of different states,' which include all kinds of civil causes between those parties.

4 H. Storing, The Complete Anti-Federalist 96-97 (1981) (reprinting Letter of Agrippa to the Massachusetts Convention (Jan. 14, 1788)).

20 See 1 W. Crosskey, supra note 18, at 614-615; cf. Chisholm v. Georgia, 2 U.S. (2 Dall.) 419, 431 (1793) (Iredell, J., dissenting) (stating that "it was perhaps a proper instance of caution in congress to guard against the possibility" that controversies might be taken to include criminal cases by including the word "civil" in the First Judiciary Act).

In an earlier article, Amar contended that the suggested distinction is undermined by article III's original jurisdiction clause, in which the word "cases" 
The First Judiciary Act is consistent with this understanding. The Act vests criminal jurisdiction in the lower federal courts in federal question and admiralty cases. ${ }^{21}$ It also vests original jurisdiction in the Supreme Court in suits to which ambassadors and other diplomats are parties, a grant that, in marked contrast to the grant of original jurisdiction over state-as-party cases, is not restricted to civil suits. ${ }^{22}$ By contrast, the Act appears to limit the party-based jurisdictional grants to civil cases. ${ }^{23}$

refers to jurisdiction where a state is a party (previously defined in article III as encompassing only controversies) als well as the ambassador jurisdiction. See Amar, Neo-Federalist View, supra note 1 , at $244 \mathrm{n} .128$. But it hardly seems implausible that article III, having once distinguished cases from controversies, would in the next paragraph use the single, broader term as a catchall.

More recently, Amar implicitly criticized the suggested distinction by offering a different explanation: in a " 'case' . . . a judge's law-declaring role is paramount, and [in] a 'controversy' . . . a judge's ability as a dispute-resolver is highlighted." Amar, Law Story (Book Review), 102 Ha.Rv. L. Rev. 688, 717 (1989) (quoting Robert Pushaw). This sounds to me like an infusion of 20 th century concepts into 18 th century language. But of. infra note 59 (perhaps committing the same sin).

21 See Judiciary Act of 1789, ch. 20, §§ 9, 11, 1 Stat. 73, 76-79.

22 See id. $\$ 13,1$ Stat. at 80-81. Charles Warren reports that the only federal statute to provide for a criminal trial before the Supreme Court involved a criminal prohibition directed at foreign consuls. See Warren, New Light on the History of the Federal Judiciary Act of 1789, 37 HARv. L. REv. 49, 94 n.98 (1923). It is uncertain whether in fact the federal courts would have entertained a state law prosecution against an ambassador, given the strong tradition that one sovereign will not enforce another's penal laws. Compare The Antelope, 23 U.S. (10 Wheat.) 66, 123 (1825) (articulating that tradition) with 28 U.S.C. $\$ \$ 1442-43$ (1982) (authorizing federal court adjudication of state criminal prosecutions against federal officials).

23 See Judiciary Act of 1789, ch. 20, $\S 9,11-13,1$ Stat. 73, 76-81; see also Wisconsin v. Pelican Ins. Co., 127 U.S. 265, 297-98 (1888) (concluding that article III's grant of original jurisdiction to the Supreme Court in suits by a state against a citizen of another state does not extend to criminal matters).

Two possible objections to the statement in the text should be noted. First, $\$ 12$ 's grant of removal jurisdiction in "any action" commenced in state court between citizens of the same state involving conflicting land grants was not expressly limited to civil cases. In theory, conflicting land grants could arise in criminal trespass actions under state law (or under the common law), and though $\S 12$ plainly did not contemplate prosecution by the United States, perhaps it could have encompassed a private prosecution. That possibility seems unlikely, however, for $\$ 12$ requires that "the matter in dispute exceed[] the aforesaid sum or value of five hundred dollars," and elsewhere in the Act, jurisdictional amount limits described by that kind of language apply only to civil actions. See Judiciary Act of 1789, ch. 20, $\S \S 9,11,1$ Stat. 73, 76-79. By contrast where the Act limits criminal jurisdiction by "amount in controversy," different wording is used. See id. $\$ 9,1$ Stat. at 76-77 (giving the district courts criminal jurisdiction "where no punishment other than ... a fine not exceeding one hundred dollars" is to be inflicted).

Second, $\$ \$ 9$ and 11 confer jurisdiction over all crimes "cognizable under the authority of the United States." Sections 9 and 11 could be viewed as extending party-based jurisdiction to criminal cases if, but only if, (a) the first Congress, in drafting those provisions, contemplated the institution of common law criminal 


\section{B. The Significance of the Text}

Even if one discounted this alternative explanation, the question would remain whether article III's use of "all" strongly supports Amar's distinction between the two tiers. Though Amar states that the textual argument alone is not "fully satisfying"24 and relies on other arguments, his discussion returns repeatedly to this "dramatic" textual variation. ${ }^{25}$ Do the records of the constitutional period support the weight that he places on the word "all"?

\section{All Quiet on the Two-Tier Front}

At the Constitutional Convention, the plan that emerged from the deliberations of the Committee of the Whole stated simply: "Resolved, that the jurisdiction of the national Judiciary shall extend to cases which respect the collection of national revenue: impeachments of any national Officers: and questions which involve the national peace and harmony."26 To that juncture, there is no recorded suggestion of different tiers within the judicial power.

When that plan came before the Convention on July 18, two modifications were made. First, the jurisdiction over impeachments was stricken. ${ }^{27}$ Second,

[s] everal criticisms having been made on the definition; it was proposed by Mr. [Madison] so to alter as to read thus-'that the jurisdiction shall extend to all cases arising under the Natl. laws: And to such other questions as may involve the Natl. peace and harmony.' which was agreed to nem. con. ${ }^{28}$

Amar views this second change as noteworthy because it "highlights the special significance ... of federal question jurisdiction" and "strongly hints at a two-tier jurisdictional scheme . . .."29 There is no doubt that the Convention delegates stressed the importance of federal jurisdiction repeatedly, but the two-tier structure is less

prosecutions by the United States, (b) those prosecutions otherwise involved no issue (however uncontroversial or peripheral) of federal law, see Osborn v. Bank of the United States, 22 U.S. (9 Wheat.) 738, 818-28 (1824), and (c) Congress did not view federal prosecutions for common law offenses as arising under federal law.

24 Amar, supra note 6, at 1566.

25 See id.; see also id. at 1501, 1507-08, 1524-25, 1543, 1547, 1558-59; Amar, Neo-

Federalist View, supra note 1, at 240-42, 253, 254 n.160.

261 ReCoRDs, supra note 14, at 231.

272 id. at 46.

28 Id. (Madison's notes); see also id. at 132-33 (slightly different version of Madison's resolution).

29 Amar, Neo-Federalist View, supra note 1, at 243 n.127. 
apparent to me. The difference in phrasing between "all" and "such other questions" may signify not that the second set of cases should be understood as less mandatory than the first, but only that the second was a catch-all category, necessarily less well-defined than the "arising under" category.

Indeed, the hypothesis that the Convention's amendment suggests that federal question cases were to be mandatory, while all other cases affecting peace and harmony were not, does not fit well with contemporary views of admiralty jurisdiction. That federal courts should have some form of admiralty jurisdiction, in order to promote national peace and harmony, was among the least controversial aspects of the debate over the national judiciary. ${ }^{30}$ Yet under Amar's reading of the July 18 amendment, admiralty would fall within the non-mandatory tier. This prospect creates further doubt that that amendment set forth a two-tier structure.

Article III's list of nine heads of jurisdiction, and its selective use of the word "all," derive from the draft prepared by James Wilson for the Committee of Detail. ${ }^{31}$ There is no direct evidence that any member of the committee, or any other delegate, understood the draft as creating mandatory and non-mandatory tiers of federal judicial power. The short of the matter is that Amar has not identified

30 See The Federalist No. 80, at 502 (A. Hamilton) (Wright ed. 1961) ("The most bigoted idolizers of State authority have not thus far shown a disposition to deny the national judiciary the cognizance of maritime causes."); infra note 87 and accompanying text. In the first Congress, anti-federalists moved to strip the lower federal courts of all jurisdiction other than admiralty. See Warren, supra note 22 , at 67 $68,123$.

The reasons for the lack of controversy about admiralty jurisdiction are several. First, before the Revolutionary War, maritime law had been administered by British vice-admiralty rather than colonial courts. "General admiralty jurisdiction was thus not one that state courts had been accustomed to exercise; and state legislatures proved hesitant in conferring it upon them." HART \& WECHSLER, supra note 2, at 14. Under the Articles of Confederation, the first and last national court was established to adjudicate appeals from state courts in piracy and capture cases. See id. at 5 n.18. During that period, the experience of "largely uncontrolled activity by a body of state courts, more or less contemptuous of national reviewing authority, . . . led the national leaders to agree upon the necessity for federal admiralty courts." $D$. Robertson, Admiralty and Federalism 103 (1970).

Though neither the Committee of the Whole's language nor that of the July 18 amendment specifically referred to admiralty jurisdiction, some version of that jurisdiction had been presented 1.0 and discussed in the Convention. See, e.g., 1 RECORDS, supra note 14, at 21-22 (Randolph proposal); see also 2 id. at 136 (Pinckney plan, which may not have been presented to the Convention proper). See generally $D$. ROBERTSON, supra, at 6-17.

31 See 2 RECORDs, supra note 14, at 186-87. For discussion of Amar's argument that an earlier draft, prepared by Edmund Randolph for the Committee, supports his argument, see infra note 35 . 
any speech at the Convention or ratification debates that articulated a distinction between mandatory and permissive jurisdictions. ${ }^{32}$ The lack of articulation at the Convention is not so probative given the state of the surviving records and the shifting content of the judiciary article. More telling is the lack of evidence from the ratification debates, which featured quite detailed discussions of the finished text of article III by many participants, including important figures like Madison and Wilson. Furthermore, though Amar relies heavily on views expressed a quarter of a century later by Justice Story, it is far from clear that Story believed in Amar's distinction. ${ }^{33}$

32 See Amar, Neo-Federalist View, supra note 1, at 243 n.126.

33 Amar sets forth the relevant passages from Story's opinion in Martin $v$. Hunter's Lessee, some of which suggest that the entire judicial power is mandatory. See Amar, supra note 6, at 1502 n.9. A decision in which Story participated two years later, while sitting as a circuit judge, adds to doubts that he read article III as having two tiers. In White v. Fenner, 29 F. Cas. 1015 (C.C.R.I. 1818) (No. 17,547) (per curiam), the court dismissed, as outside its diversity jurisdiction, a suit in which neither party was a citizen of the forum. The opinion stated, however, that

the constitution declares that it is mandatory to the legislature, that the judicial power of the United States shall extend to controversies 'between citizens of different states'; and it is somewhat singular, that the jurisdiction actually conferred ... should have stopped so far short of the constitutional extent .... But ... [t] .... [t $]$ he suit must . . . be dismissed."

Id. at 1015-16.

But neither Story's opinion in Martin nor his joining the decision in White provides a good test of his adherence to the two-tier thesis. Martin's discussion of Congress's obligation to vest federal question jurisdiction was pure dictum, as Congress had done so. In White, though statutory jurisdiction was lacking, the case was within Amar's "non-mandatory" tier.

Story did participate, however, in three decisions squarely testing his allegiance to the two-tier thesis. In each case, the state court had upheld a claim of federal right; the losing party sought Supreme Court review; and the defendant in error argued that the Court had no statutory jurisdiction. Were Story a true adherent of the two-tier thesis, he would have held unconstitutional Congress's failure to vest federal question jurisdiction over these cases in some federal court. Instead, he joined with the Court in simply dismissing for want of statutory jurisdiction. See infra note 74 .

Herbert Wechsler has suggested, further, that Story's entire dictum in Martin should be read in light of his "sustained campaign to stimulate the Congress to enlarge the jurisdiction of the lower courts and to expand the fragmentary corpus of the national statutory law." Wechsler, The Appellate Jurisdiction of the Supreme Court: Reflections on the Law and the Logistics of Direct Review, 34 WASH. \& LEE L. REv. 1043, 1046 (1977); see also G. Gunther, Constitutional Law 49-50 (11 th ed. 1985) (detailing Story's lobbying activities); Gunther, supra note 2, at 907 n.55 (stating that although Story and John Marshall were concerned about proposals to repeal the Supreme Court's jurisdiction to review state court decisions, neither they nor their colleagues suggested that such a repeal would be unconstitutional).

Amar contends that Story placed more weight on the two-tier thesis in his 1833 Commentaries than in Martin. See Amar, supra note 6, at 1502 n.9. Perhaps that is so, 
Although the distinction may have been so self-evident that no one remarked on it, there are reasons to doubt that explanation. Some of the plans for the judiciary presented at the Convention also included the word "all" in describing certain jurisdictional categories. To be sure, these plans were not adopted; article III was. But examination of them leaves two impressions: that Amar's ranking of the relative importance of the two tiers was not universally shared, ${ }^{34}$ and that the word "all" may have been used quite haphazardly rather than to distinguish mandatory and permissive jurisdictions. ${ }^{35}$

A venerable source, The Federalist No. 80 , casts further doubts on

but as Amar concedes, see id., the Commentaries remain quite equivocal on whether all of the federal judicial power, or only the first tier, is mandatory. See $3 \mathrm{~J}$. STORY, supra note $5, \S 1696$, at $572-73$ (Jurisdiction is mandatory "in that class of cases, at least, where it has declared that it shall extend to 'all cases.' "); id. $\S 1745$, at 618 (quoting the wavering language from Martin itself).

34 For example, Randolph's Virginia plan used "all" in describing jurisdiction over piracy and felonies on the high seas, but not as to succeeding clauses (which included "cases in which foreigners or citizens of other States . . . may be interested" and "cases ... which respect ... questions which may involve the national peace and harmony"). See 1 RecoRDs, supra note 14, at 21-22. Either "all" does not modify federal question jurisdiction, or modifies both federal question and diversity jurisdiction. Hamilton's plan (never presented to the Convention, but possibly the basis for his speech of June 18,1787 ) modified every proposed head of jurisdiction with the word "all"-including several party-based jurisdictions. See 3 id. at 626; see also infra note $\mathbf{3 6}$ and accompanying text.

35 For example, in Paterson's New Jersey plan, "all" modified piracy and capture cases, cases affecting ambassadors, and cases in which foreigners may be interested, but not cases involving the construction of treaties, despite the great importance assigned to this last category in the Convention Debates. See 1 Records, supra note 14, at 244.

The Randolph Draft for the Committee of Detail read as follows (the bracketed material reflects modifications in Rutledge's hand):

The jurisdiction of the supreme tribunal shall extend

1. to all cases, arising under laws passed by the general [Legislature]

2. to impeachments of officers, and

3. to such other cases, as the national legislature may assign, as involving

the national peace and harmony,

in the collection of the revenue

in disputes between citizens of different states [in disputes between a

State \& a Citizen or Citizens of another State]

in disputes between different states; and

in disputes, in which subjects or citizens of other countries are

concerned

[\& in Cases of Admiralty Jurisdn].

2 id. at $146-47$ (footnote omitted).

Amar argues that the contrast between the first and third categories contains the seeds of the two-tier approach. See Amar, Neo-Federalist View, supra note 1, at 243. It is worth noting that "all" modifies federal question but not admiralty jurisdiction, even though the latter was perhaps the least controversial component of the federal judicial power. See supra note $\mathbf{3 0}$ and accompanying text. But because the addition of 
Amar's textual argument. There, Hamilton asserted that national judicial power should extend to cases 1) arising under federal statutes, 2) arising under the Constitution, 3) in which the United States is a party, 4) involving national peace (whether relating to intercourse with foreign nations or between states), 5) of admiralty or maritime jurisdiction, and 6) in which state tribunals would lack impartiality. Hamilton used the word "all" to describe each of the six categories, subject matter and party based, alike. ${ }^{36}$ Moreover, after discussing the first two categories, Hamilton said: "Still less need be said in regard to the third point. Controversies between the nation and its members or citizens, can only be properly referred to the national tribunals."37 Thus, for him, some party-based cases were at least as important as federal question cases. Finally, The Federalist No. 80 does not group the various jurisdictions by subject matter and party basis. Rather, Hamilton's fourth category included the ambassador jurisdiction and disputes between states, thus mixing Amar's two tiers. ${ }^{38}$

The Federalist Papers were, of course, political debate, not consti-

admiralty is in the hand of John Rutledge, it is quite possible that Randolph's omission and Rutledge's failure to include the word "all" were both oversights.

In addition, however, any federal court jurisdiction to try impeachments would surely have been mandatory even though the word "all" is missing from the second head listed above. See Amar, Neo-Federalist View, supra note 1, at 244 n.128 (conceding the point, but discounting the significance of the omission).

36 See The Federalist No. 80, supra note 30, at 499-500. Hamilton was not alone among prominent federalists whose statements in the ratification debates drew no distinction between Amar's two-tiers. See, e.g., 2 Elliot's Debates, supra note 5, at 489-91 (remarks of James Wilson); 3 id. at 532-33 (remarks of James Madison).

37 The Federalist No. 80, supra note 30, at 500 (emphasis added).

38 See id. at 504 . Hamilton was by no means the only convention delegate who linked the jurisdiction over treaties, foreign diversity, ambassadors, and interstate disputes as necessary to promote internal and international harmony. See, e.g., 3 Elliot's Debates, supra note 5, at 532-34 (remarks of James Madison to Virginia Ratifying Convention); id. at 570-71 (remarks of Edmund Randolph to Virginia Ratifying Convention); $4 \mathrm{id}$. at 158-59 (remarks of William Davie to North Carolina Ratifying Convention); see also infra note 167.

Similarly, in the Pennsylvania Ratifying Convention, James Wilson's defense of the "mandatory" jurisdiction over cases arising under federal treaties sounds very much like his defense of the "permissive" jurisdiction over controversies with foreign citizens. As to each, he argued that federal jurisdiction was needed to counteract the risk that states would pass laws obstructing the payment of debts to foreigners-a prospect that would impair the United States' relations with foreign nations. See 3 Ellior's DeBates, supra note 5, at 489-90, 492-93.

More generally, Wilson discussed all of the nine heads of jurisdiction seriatim. For each he quoted or paraphrased article III's language referring to "all cases" or to "controversies." He did not, however, suggest that "all" was meant to separate mandatory from permissive categories of jurisdiction. 
tutional exegesis. It is possible that Hamilton overlooked the distinction on which Amar insists, or thought it too technical, or too controversial, to merit discussion. Still, The Federalist No. 80 adds to my doubts about the force of Amar's textual argument.

\section{Contemporary Views of the Relative Significance of the Two Tiers}

A different argument for the two-tier thesis would emphasize that the framers considered the subject matter heads of jurisdiction more important than the party-based heads. I have noted already the importance generally assigned to the federal maritime jurisdiction. But it is far from clear that contemporaries considered the other two subject matter heads to be more important than all of the party-based heads. ${ }^{39}$

Some pertinent evidence is found in the various plans offered at the Convention. They do not square with Amar's theory; some included categories from the non-mandatory tier, or excluded categories from the mandatory tier, or both. ${ }^{40}$ Indeed, Professor Holt has recently argued that a central reason for creation of a national judiciary was to establish diversity and alienage jurisdictions to

39 But see Amar, Neo-Federalist View, supra note 1, at 243-45 \& nn.127-30.

The ambassador jurisdiction is the only one of the three subject-matter heads that appears twice in article III-orce in the initial listing of the heads of jurisdiction, and later in the description of the original jurisdiction. As Amar repeatedly notes, both times it is modified by the word "all." See supra note 16 and accompanying text. Yet it is striking how often Amar, in discussing the importance or mandatory nature of the first-tier, refers only to federal question and admiralty cases. See, e.g., Amar, supra note 6 , at 1508, 1512-13, 15.27 n.85, 1529-30, 1544-45, 1556-57, 1558-59.

Amar argues that if cases affecting ambassadors seem less important to national interests than cases to which the United States is a party or controversies involving a state, the reason is that the latter categories are likely to involve federal questions. For critical discussion of this point, see infra notes 49, 134 and accompanying text.

40 Randolph's Virginia Plan, for example, included party-based jurisdiction where citizens of other states or foreign countries might be interested. It set forth no separate jurisdiction over cases involving ambassadors and no general federal question jurisdiction (though it proposed jurisdiction over "questions which may involve the national peace and harmony"). See 1 Records, supra note 14, at 21-22. Patterson's New Jersey Plan listed cases in which foreigners may be interested before listing its limited jurisdiction relating to the construction of federal treaties and some federal statutes, and did not provide for a general federal question jurisdiction. See id. at 244. Pinckney's plan gave the Supreme Court jurisdiction where the United States was a party but not in cases involving ambassadors. See 2 id. at 136. Hamilton's plan gave the Supreme Court original jurisdiction over cases involving the United States, or two or more states, but only appellate jurisdiction of cases in which constitutional rights were at issue, and (perhaps through an oversight) did not include admiralty jurisdiction. See 9 id. at 626. 
respond to problems of localism apparent in debtor-creditor difficulties after the Revolution. ${ }^{41}$ Noting the severity of those difficulties and the special problems experienced by British creditors and Loyalist property owners, he goes so far as to assert that "alienage jurisdiction was the most important head of jurisdiction in article III." 42 One need not share that conclusion to appreciate how much more importance the party-based jurisdictions assumed in 1787 than they do today.

As for the ratification debates, though I have only dipped into the records, I have found a number of fragments that are hard to square with the two-tier thesis. On the federalist side, I return to Hamilton's The Federalist No. 80 and to discussions by such figures as James Madison and James Wilson. ${ }^{43}$ More generally, one jurisdiction that was particularly free from controversy was that in disputes between two states. ${ }^{44}$ Its necessity is apparent: on the one hand, each state might lack power to subject the other (absent its consent) to suit; ${ }^{45}$ on the other, the exercise of jurisdiction raises an obvious problem, in Amar's words, of "home field advantage."46 It is no doubt because neither of these alternatives is tolerable that Justice Story called federal jurisdiction over such disputes "essential to the preservation of the peace of the nation."47 Amar's argument that some categories of the federal judicial power are mandatory, but not this one, strikes me as implausible.

On the anti-federalist side, there is little doubt that the diversity jurisdiction drew the strongest attacks. ${ }^{48}$ But some anti-federalist writers viewed other party-based heads (those between states, between co-citizens claiming under different states' land grants, in which the United States was a party, ${ }^{49}$ or in which foreigners were

41 See Holt, "To Establish Justice": Politics, the Judiciary Act of 1789, and the Invention of the Federal Courts, 1989 Duke L.J. 1421, 1473.

42 Id. at 1466 n.170.

43 See supra notes $36-38$ and accompanying text.

44 See, e.g., 3 Elliot's Debates, supra note 5, at 532-33 (remarks of James Madison).

45 But see Nevada v. Hall, 440 U.S. 410, $414-27$ (1979) (holding that the Constitution does not preclude a state from subjecting an unconsenting sister state to suit).

46 Amar, Original Jurisdiction, supra note 1, at 477. 96-101.

$473 \mathrm{~J}$. STORY, supra note 5, 81673 , at 543; see also infra text accompanying notes

48 See Clinton, A Guided Quest, supra note 4, at 801 (citing sources for this proposition).

49 On the three heads just mentioned, see 4 H. SToring, supra note 19, at 131- 
parties ${ }^{50}$ ) as appropriate, while doubting the appropriateness of "arising under" jurisdiction. Another, the writer Brutus, treated maritime cases together with controversies to which the United States is a party and those between states as appropriate for national courts, as "none but the general government, can, or ought to pass laws on their subjects." 51 In a similar vein, the Virginia Convention proposed an amendment that would have limited federal question jurisdiction to cases arising under treaties, but also included partybased jurisdiction where the United States was a party, in suits between states, and in disputes involving land grants from different states. ${ }^{52}$

None of this evidence "proves" that Amar's thesis is mistaken, and Amar is surely right to caution against requiring discovery of a "smoking gun." 53 For him, the use of the word "all" carries important meaning, and places the burden of proof on those who dispute its significance. Indeed, he taxes me for not having identified eighteenth century figures who denied its significance. ${ }^{54}$ But I am not sur-

32 (reprinting Essay by Candidus (Dec. 20, 1987) (attributed to Samuel Adams or his follower Benjamin Austin, Jr.)).

Amar suggests that insofar as suits brought by the United States are today viewed as especially important, it is because federal law is likely to govern. See Amar, supra note 6 , at 1508 . The point seems dubious to me. Though formally federal common law governs the proprietary relationships of the United States, in practice the law applied is presumptively state law. See, e.g., United States v. Kimbell Foods, 440 U.S. $715,739-40$ (1979).

Moreover, there is little reason to think that the framers viewed such actions as important because federal law would govern. "The extent to which state or federal law governed in such suits was not subjected to precise analysis; it was simply assumed or asserted that the case was to be brought under "local law." HaRT \& WECHSLER, supra note 2, at 863; see also Cotton v. United States, 52 U.S. (11 How.) 228 (1850); cf. 4 The Founders' Constitution 357 (P. Kurland \& R. Lerner eds. 1987) (reprinting W. RaWle, A View of the Constitution of the United States (2d ed. 1829)). The framers' reason for creating this jurisdiction was not the one Amar posits. See, e.g., 2 Elliot's DEBATES, supra note 5, at 490 (remarks of James Wilson) ("[T]he universal practice of all nations has, and unavoidably must have, admitted of this power" to decide cases in which the nation is a party.); see also $3 \mathrm{~J}$. STORY, supra note $5, \S 1668$, at 53'7 ("It would be a perfect novelty in the history of national jurisprudence, as well as of public law, that a sovereign has no authority to sue in his own courts."); id. $\S 1744$ :, at 617 (explaining article III's failure to use the word "all" in describing this jurisdiction as designed to avoid subjecting the sovereign to suit).

50 See 4 H. Storing, supra note 19, at 112 (reprinting Letter from Agrippa to the Massachusetts Convention (Feb. 5, 1788) (attributed to James Winthrop)).

512 H. Storing, supra note 19, at 428-29 (reprinting Essay of Brutus (Feb. 21, 1788)).

52 See 3 Elliot's Debates, sufra note 5, at 660-61.

53 See Amar, supra note 6, at 1566; see also infra text accompanying notes 139-63.

54 Amar, supra note 6, at 154 S n.159. 
prised that these statesmen did not devote their time to denying a proposition that no one seemed to be affirming. For me, Amar's thesis is unconvincing in light of the striking absence of even a single contemporary source setting forth the two-tier thesis, the plausibility of the explanation that "all" was meant to reinforce the breadth of cases (as distinguished from controversies), and the evidence that "all" was often used by the important figures at the Convention and in the ratification debates to mean something other than what Amar suggests.

\section{The First Judiciary Act and the Two-Tier Thesis}

In discussing the meaning of article III, many have assigned great weight to the views of members of the first Congress, a number of whom were delegates to the Constitutional Convention or participants in the ratification debates. ${ }^{55}$ Amar's argument is to some extent in that tradition. He asserts that the First Judiciary Act lends support to his thesis, while some of his critics suggest the opposite view. Who has the better of the argument?

\section{A. The First Judiciary Act: "Gaps" in the "Mandatory" Tier}

The starting point for resolving this question must be to examine whether the Act fully vested jurisdiction in all three of Amar's "mandatory tier" categories.

\section{The "Arising Under" Jurisdiction and Supreme Court Review of State Court Judgments}

Since the First Judiciary Act did not give the lower federal courts general "arising under" jurisdiction, that "mandatory" jurisdiction could be fully vested in the federal judiciary only if the Supreme Court had plenary appellate jurisdiction over state court judgments. But the pertinent provision, section 25 of the First Judiciary Act, ${ }^{56}$ falls short. Each of its three clauses appears to restrict review to state court decisions denying claims of federal right or immunity. ${ }^{57}$ It was

55 See, e.g., Wisconsin v. Pelican Ins. Co., 127 U.S. 265, 297 (1888); Casto, The First Congress's Understanding of Its Authority Over the Federal Courts' Jurisdiction, 26 B.C.L. REv. 1101, 1103, 1125-26 (1985); Gunther, supra note 2, at 906. For discussion of whether those views should have great weight, see infra text accompanying notes 139-63.

56 Judiciary Act of 1789 , ch. $20, \S 25,1$ Stat. $73,85$.

57 Section 25 permitted review of

a final judgment or decree . . . where is drawn in question the validity of a 
not until 1914 that Congress granted the Court jurisdiction without regard to whether the state court had decided the federal issue. ${ }^{58}$

On first blush, then, it appears that at least until 1914, article III's "arising under" juriscliction was not fully vested in the federal courts. ${ }^{59}$ From the start, Amar has recognized the difficulty posed

treaty or statute of, or an authority exercised under the United States, and the decision is against their valitity; or where is drawn in question the validity of [state action as] repugnant to the constitution, treaties or laws of the United States, and the decisicn is in favour of such their validity, or where is drawn in question the construction of any clause of the constitution, or of a treaty, or statute of, or conmmission held under the United States, and the decision is against the title, right. privilege or exemption specially set up or claimed by either party, under such clause of the said Constitution, treaty, statute or commission

....

Id. at 85-86 (footnote omitted and emphasis added).

58 Act of December 23, 1914, ch. 2, 38 Stat. 790. See generally F. FrankfurTer \& J. Landis, The Business of the Supreme Court 188-98 (1928).

59 There is one other respect in which $\$ 25$ did not fully vest the federal question jurisdiction. That section permitted review of state court decisions via writ of error, which remained the exclusive basis for review until 1914 and was not entirely displaced until 1928. See HART \& Wechsler, supra note 2, at 502-03. The technical nature of the writ of error was generally understood as precluding review of state court findings of fact, in non-jury as well as jury cases. See, e.g., Egan v. Hart, 165 U.S. 188, 189 (1897); Note, Supreme Court Review of State Court Findings of Fact, 55 HaRv. L. REv. 644, 645-46 (1942). Thus, article III's “arising under" jurisdictionwhich even on appeal extends to questions of fact as well as law-was not fully vested.

For some, the independent and adequate state ground doctrine would constitute an additional gap in the federal question jurisdiction, one continuing to this day. At least since the decision in Eustis v. Bolles, 150 U.S. 361, 370 (1893), the Supreme Court has refused to decide federal questions where the state court judgment rests on an adequate and independent state ground. Many commentators argue that there is no constitutional barrier to the Supreme Court's exercising jurisdiction in such cases. See, e.g., Matasar \& Bruch, Procedural Common Law, Federal Jurisdictional Policy, and Abandonment of the Adequate and Independent State Grounds Doctrine, 86 CoLUM. L. REv. 1291, 1294-1315 (1986); Sandalow, Henry v. Mississippi and the Adequate State Ground: Proposals for a Revised Doctrine, 1965 Sup. CT. REv. 187, 201-03; Note, The Untenable Nonfederal Ground in the Supreme Court, 74 HARv. L. Rev. 1375, 1379 (1961) (arguing that the constitutional basis of the doctrine is questionable); Note, Supreme Court Disposition of State Decisions Involving Non-Federal Questions, 49 YALE L.J. 1463 (1940). I confess to finding these arguments highly problematic, and Amar may well share my doubts. But if the argument were accepted, then another gap exists, at least insofar as the adequate state ground doctrine is viewed as an interpretation of the jurisdictional statute rather than a self-imposed (and judicially reversible) doctrine of self-restraint.

There is one last possible "gap" in that jurisdiction, though I admit that raising it requires looking at Amar's theory through a 20th century lens. I suspect that Amar, with his strong nationalist inclination, might well view article III's "arising under" clause as permitting Congress to confer protective jurisdiction-that is, jurisdiction to hear cases falling within a subject matter that Congress has regulated, or constitutionally could regulate, even if the case involves no issue of federal law. 
for his thesis. ${ }^{60}$ In 1985, he responded by analogizing Supreme Court appellate jurisdiction under article III to district court "arising under" jurisdiction under 28 U.S.C. $§ 1331$, and suggested that review of a state court decision might be viewed as arising under federal law (for purposes of article III) only if the appellant claims a federal right. ${ }^{61}$ Beyond difficulties with the analogy, ${ }^{62}$ there lies a simple problem: an appeal from a state court's decision upholding a federal right either does or does not fall within article III's "arising under" jurisdiction. If it does not, then in 1914, Congress unconstitutionally extended the Supreme Court's jurisdiction beyond the bounds of article III. If (as I think) it does, then there was a very large "gap" prior to 1914.63

See Amar, Neo-Federalist View, supra note 1, at $266 \mathrm{n} .199$ (offering an analogy to protective jurisdiction). See generally HART \& WECHSLER, supra note 2, at 975-89 (discussing the meaning and validity of protective jurisdiction). If so, then unless the "mandatory" "arising under" jurisdiction in fact has mandatory and non-mandatory components, see infra note 63 , under his theory the judicial power must extend to all cases in which Congress could constitutionally confer protective jurisdiction. It is difficult to imagine how Congress could draft legislation complying with that requirement.

60 See Amar, Neo-Federalist View, supra note 1, at 262-65.

61 See id.

62 Not only do the meanings of the statutory and constitutional provisions differ, see, e.g., Franchise Tax Bd. of Cal. v. Construction Laborers Vacation Trust, 463 U.S. 1, 8-9 n.8 (1983); Verlinden B.V. v. Central Bank of Nigeria, 461 U.S. 480, 494-95 (1983), but so do the nature of original district court and Supreme Court appellate jurisdiction. See HART \& WEchsLer, supra note 2, at 530-31, 983. In the Supreme Court context, there is a state court decision that has resolved various issues; one can determine if the decision rested on federal law, and if so, how the issue was resolved. By contrast, when a case is filed in a district court under 28 U.S.C. $\S 1331$, not only is it impossible to be certain what issues will arise or be determinative, but it is, obviously, impossible to ask whether a prior adjudication upheld or denied the federal right.

Until amended in $1867, \S 25$ conferred jurisdiction only if the reviewable federal issue was apparent from the face of the record. Compare Judiciary Act of 1789, ch. 20, $\S 25,1$ Stat. 73, 85 with Act of February 5, 1867, ch. 28, 14 Stat. 385, 386 (repealing that limitation). The "record" did not include the state court's opinion. See Williams v. Norris, 25 U.S. (12 Wheat.) 117, 118-19 (1827). Prior to 1867, however, the Supreme Court seems to have been able to determine (whether from the record or from counsel's arguments) what the state court had in fact decided. See, e.g., Ryan v. Thomas, 71 U.S. (4 Wall.) 603, 604 (1866); Commonwealth Bank of Ky. v. Griffith, 39 U.S. (14 Pet.) 56, 57 (1840).

63 One might try to read the "arising under" jurisdiction as having a mandatory component (review of claims of denial of federal rights) and a non-mandatory component (review of other claims). See Amar, Neo-Federalist View, supra note 1, at 266 n.199; cf. Sager, supra note 3, at 52-57 (reading article III as requiring federal oversight of the states' compliance with the federal Constitution, and $\$ 25$ as consistent with that understanding). On that reading, though, Amar's textual emphasis on "shall" and "all," and many of his structural arguments about the importance of article III adjudication of all federal question cases, miss the mark. 
Though not jettisoning his argument that article III's appellate jurisdiction is narrow, ${ }^{64}$ Amar now stresses the quite different explanation that section 25 was really quite broad: "In virtually every case in which one party argues for a federal 'right,' the other side can argue that it has a federal 'immunity'-which is simply another way of saying that one's opponent has no federal right."65 He says, for example, that if a state court upholds a criminal defendant's bill of attainder claim, the state may seek review under the tenth amendment. ${ }^{66}$

Beyond the tension (if not outright conflict) between the two arguments, I find this second argument no more convincing. Immunity usually means something different from a plaintiff's lack of a claim. Suppose, for example, that in a libel action against a newspaper, a state court found the plaintiff to be a public figure. Ordinarily, we would say that, absent proof of actual malice, the defendant newspaper has an immunity or privilege. We do not mean that the newspaper did not defame the plaintiff and cause him injury, but rather that even assuming it did, supervening federal law affords a defense. Nor do I think we would say that the plaintiff, if he sought Supreme Court review of the state court's decision that he was a public figure,

64 See Amar, supra note 6, at 1529.

65 Id. at 1530 . His initial article mentioned this second argument, though in a far briefer and more tentative way. See Amar, Neo-Federalist View, supra note 1, at 264. The argument was previously made in Ratner, Congressional Power over the Appellate Jurisdiction of the Supreme Court, 109 U. PA. L. REv. 157, 185-87 (1960) [hereinafter Ratner, Congressional Power].

66 See Amar, supra note 6, at 1530-31. Amar raises an important point about Supreme Court review, quite properly taking issue with the view that so long as state courts uphold federal rights, Supreme Court review is unnecessary or unimportant. See id. at 1532-33 \& n.111 (citing Bator, The State Courts and Federal Constitutional Litigation, 22 WM. \& MARY L. REv. 605, 631-35 (1981)); see also HART \& WECHSLER, supra note 2, at 554-57. For a recent expression of the view that Amar criticizes, see Michigan v. Long, 463 U.S. 1032, 1067-71 (1983) (Stevens, J., dissenting).

That point, however, does not solve the problem under $\S 25$. Suppose a state court upholds a claim that the defendant, a European bank with American offices, violated the federal Truth in Lending Act (TILA), 15 U.S.C. $\$ \S 1607,1635$ (1988). It is one thing to argue that there may be federal interests (promotion of uniformity, correcting an erroneous understanding of the TILA) in reviewing possible "overprotection" of federal rights. It is another to suggest that in seeking review, the bank possesses a justiciable "right" or "immunity" or "exemption" under federal law. See Sager, supra note 3, at 53 n.104 (distinguishing, in this context, federal rights from federal interests). Indeed, what provision of federal law would be the source of the bank's right or immunity? The TILA gives rights to borrowers and against lenders, not vice versa. The tenth amendment is in my view most plausibly read as a truism, see United States v. Darby, 312 U.S. 100, 124 (1941), but it is doubtful in any event that it confers rights on foreign citizens. 
would be asserting a federal right or immunity (a right not to be a public figure?). Amar's usage seems more than a bit unconventional.

In a 1908 decision, however, the Supreme Court upheld its jurisdiction using reasoning somewhat like Amar's, ${ }^{67}$ and three cases thereafter followed suit. ${ }^{68}$ Amar thus argues that "blame for whatever 'gaps' emerged under section 25 should be laid at the feet not of the first Congress, but of subsequent Supreme Courts and the lawyers who brought cases to them . ..."69

This conclusion seems a bit cavalier. In its first encounter with the restrictive language of section 25, the Court (per Chief Justice Marshall) dismissed the appeal in a one-page opinion, which read the statute as clearly precluding review where the state court upheld federal rights. ${ }^{70}$ Given his emphasis on textual argument, Amar should be receptive to the question why each of section 25's three clauses includes what appears to be a limitation of jurisdiction to cases where the state court refuses to recognize a federal right, if (as he argues) inclusion of that limitation makes no difference.

67 See St. Louis, Iron Mtn. \& S. Ry. v. Taylor, 210 U.S. 281, 292-93 (1908).

68 See Southern Ry. v. Crockett, 234 U.S. 725, 730 (1914) (implicitly accepting the argument); St. Louis, Iron Mtn. \& S. Ry. v. McWhirter, 229 U.S. 265, 275 (1913); Seaboard Air Line Ry. v. Duvall, 225 U.S. 477, 485-86 (1912).

Ratner cites these cases and offers an argument similar to Amar's. See Ratner, Congressional Power, supra note 65, at 185 \& nn. 135-37. Ratner also points to Palmer v. Hussey, 119 U.S. 96 (1886), but it provides weaker support for the argument. There, the state court ruled that a debtor had a valid federal discharge in bankruptcy. The creditor's appeal to the Supreme Court was based on a federal statutory provision that "no debt created by the fraud ... of the bankrupt, or ... while acting in any fiduciary character, shall be discharged ...."Id. at 98 . That provision could be viewed as giving the creditor a specific federal right that counteracted or trumped the general federal rights of debtors upon discharge. The Supreme Court did not specifically reach this question as the parties' pleadings did not establish either fraud or fiduciary duty.

The other three cases Ratner cites do not support his view. All involve state court denials of defenses, under federal law, to potential liabilities; the appellant was thus asserting that the state court gave inadequate scope to a federal immunity from liability. See Straus \& Straus v. American Publishers' Ass'n, 231 U.S. 222, 233-34 (1913) (In an antitrust action, state courts found resale price maintenance to be a violation as to uncopyrighted books but not as to copyrighted books; plaintiff sought review of denial of relief under Sherman Act as to the latter.); Illinois Central R.R.v. McKendree, 203 U.S. 514, 525 (1906) (State court decision rejected appellant's claim that regulation under which it was held liable was unconstitutional.); Nutt v. Knut, 200 U.S. 12, 18-19 (1906) (State court decision rejected appellant's claim of federal immunity from common law liability.).

69 Amar, supra note 6, at 1532.

70 Gordon v. Caldcleugh, 7 U.S. (3 Cranch) 268 (1806). For the text of $\S 25$, see supra note 57. 
Though we know very little about section 25 's drafting, ${ }^{71}$ there is an obvious explanation for the limitation. As Chief Justice Taney noted in a subsequent discussion, Congress might have feared that state courts would underprotect rather than overprotect federal rights. ${ }^{72}$

In sixteen decisions stretching from 1806 to 1902 , the Court invariably adhered to Marshall's understanding of section $25 .{ }^{73}$ Justice Story joined the three relevant decisions rendered during his tenure, ${ }^{74}$ and throughout this period not a single Justice appears to have differed on this point. ${ }^{75}$ In 1914 , Congress believed there was a

71 Amar notes that in the first Congress, Rep. Jackson of Georgia, referring to $\S 25$, said: "Sir, in my opinion, and I am convinced experience will prove it, there will not, neither can there be any suit or action brought in any of the State courts, but may, under this clause, be reversed or affirmed by being brought within the cognizance of the Supreme Court." See AnNals of Cong., supra note 14, at 815, quoted in Amar, supra note 6, at 1558. Jackson's statement was offered in support of a proposal to restrict the lower federal courts' jurisdiction to admiralty cases, leaving federal question cases to be litigated in the first instance in state courts. The debate focused on whether state courts would vigorously and impartially enforce federal law, or whether instead broader juristiction was needed in the lower federal courts. See ANNALs of Cong., supra note 14, at 779 (remarks of Rep. Smith); id. at 804 (remarks of Rep. Jackson) (state court judgres take an oath to uphold supremacy of federal law). In that context, Jackson may have been concerned primarily with the review of decisions failing to uphold claims of federal right. And though Jackson's statement quotes $\$ 25$ in its entirety, he does not focus on the restrictive language in its three clauses or indicate how he would square the language quoted above with $\S 25$ 's text. In the end, it is hard to make very much of this snippet-particularly in view of Amar's proper insistence that an enactment's language is the best evidence of legislative intent. See Amar, supra note 6, at 1547 \& n.171.

Though the legislative history of $\S 25$ is sparse, a letter written by Representative Smith of South Carolina on August 9, 1789 reflects his awareness that appeals under $\$ 25$ were not "reciprocal." See The Letters of William L. Smith, 69 S.C. Hist. Magazine 13, 22 (Rogers ecl. 1968). I thank Akhil Amar for pointing me to this letter.

72 See Commonwealth Bank of Ky. v. Griffith, 39 U.S. (14 Pet.) 56, 58 (1840).

73 The cases are cited in F. FRANKFURTER \& J. LANDIS, supra note 58, at 190 n.20.

74 See Fulton v. McAffee, 41 U.S. (16 Pet.) 149 (1842); Commonwealth Bank of Ky. v. Griffith, 39 U.S. (14 Pet.) 56 (1840); Montgomery v. Hernandez, 25 U.S. (12 Wheat.) 129 (1827).

75 In two of these cases, a single Justice entered a dissent, without opinion, to the Court's dismissal of an appeal for want of jurisdiction. See De Lamar's Nevada Gold Mining Co. v. Nesbitt, 177 U.S. 523, 529 (1900) (McKenna, J., dissenting); Roosevelt v. Meyer, 68 U.S. (1 Wall.) 512, 517 (1863) (Nelson, J., dissenting). But in each case both parties claimed rights under federal law, and in each the dissent appears to have been directed not at the Court's general understanding of $\S 25$, but rather at the application of that understanding where multiple claims of federal right collide.

In Roosevelt, the state court upheld the validity of the congressional legislation making paper notes legal tender. When the creditor sought review, the Supreme Court ruled that it had no jurisdiction because the state court had upheld the federal 
gap that needed filling. Finally, even if the "correct" interpretation of section 25 eluded the bench and bar for a century, the point remains that no Justice even hinted that the prevailing view raised any constitutional difficulty. ${ }^{76}$ For all of these reasons, Amar fails to

statute. See Roosevelt, 68 U.S. (I Wall.) at 517. Justice Nelson's dissenting vote thus appears to have taken the quite reasonable position (urged by the creditor's counsel, see id. at 515-16) that $\S 25$ permitted review of a state court's denial of the creditor's constitutional challenge to the validity of the legal tender act. That Nelson agreed with the Court's general approach to $\S 25$ is evidenced by his having joined the other cases decided while he was on the Court that found no jurisdiction to review state court decisions upholding federal rights, See Ryan v. Thomas, 71 U.S. (4 Wall.) 603 (1866); Reddall v. Bryan, 65 U.S. (24 How.) 420 (1860); Burke v. Gaines, 60 U.S. (19 How.) 388 (1856); Linton v. Stanton, 53 U.S. (12 How.) 423 (1851); Strader v. Baldwin, 50 U.S. (9 How.) 261 (1850).

In De Lamar's, an action to quiet title to a mine, both parties' claims arose under federal mining laws. The dispute revolved around the effect of certain federal statutes on the validity of plaintiff's claim; if valid, his claim would prevail; if not valid, then defendant would have title. The state court ruled for plaintiff. The Supreme Court dismissed, finding that the real dispute was about plaintiff's claim, and the mere fact that the defendant claimed under federal law was insufficient to confer jurisdiction under §25. See De Lamar's, 177 U.S. at 526-27. Justice McKenna's dissenting vote can thus be understood as accepting the argument that the state court denied defendant's claim of title under federal law, and hence under $\S 25$ he could seek review. Like Nelson, McKenna joined other decisions refusing jurisdiction because the state court had upheld the claim of federal right, see Baker v. Baldwin, 187 U.S. 61 (1902); Kizer v. Texarkana \& Ft. Smith Ry., 179 U.S. 199 (1900), though he later joined the line of decisions, discussed in the text, that looked the other way, see supra notes 67-68 and accompanying text.

76 Hart $\mathcal{E}$ Wechsler cites Commonwealth Bank of Ky v. Griffith, 39 U.S. (14 Pet.) 56 (1840), for the proposition that the Supreme Court viewed its appellate jurisdiction as within the scope of congressional prerogative. Amar's rejoinder is that Taney's opinion in Griffth is "egregious" and "sloppy" and deserves less weight than Story's opinion in Martin v. Hunter's Lessee, 14 U.S. (1 Wheat.) 304 (1816). See Amar, supra note 6, at 1531-32. In response, I would note these points:

1. Story's opinion wavers considerably. At times it suggests the two-tier distinction, but at other times it suggests that the entire judicial power must be vested. See Amar, supra note 6, at 1502 n.9; see also supra note 33 (noting doubts that Story adhered to a mandatory view of any sort).

2. In discussing the existence of jurisdiction under $\$ 25$ in Martin, Story italicized the words "the decision is against the title, right, privilege, or exemption, specially set up or claimed by either party under such clause," and proceeded to observe that the Virginia court had "denied the validity of a statute of the United States." Martin, 14 U.S. (1 Wheat.) at 353.

3. In Martin, because statutory jurisdiction under $\S 25$ was clear, any implication about the scope of $\S 25$ in other cases, or about the constitutionality of a less than plenary interpretation of $\S 25$, was dictum.

4. When the issue was squarely presented to the Court in Griffith, Story joined Taney's "sloppy" opinion.

As for the particular application of $\$ 25$ in Griffith, Amar suggests that the plaintiff in error might have claimed a denial of rights under the full faith and credit clause, for a Missouri court had refused to apply a Kentucky law, finding it invalid under the federal Constitution. See Amar, supra note 6, at 1532. I am no expert on full faith 
convince me that section 25 did not leave a very large gap in federal court "arising under" jurisdiction.

I might add a related point in view of Amar's reply to this Article. There he quotes from extra-judicial commentaries by John Marshall and Joseph Story, and contends, more generally, that both Justices' views are consistent with his thesis. ${ }^{77}$ Elsewhere, I raise a number of questions about Amar's description of their views. ${ }^{78} \mathrm{Par}-$ ticularly unpersuasive, because not adequately set in context, is Amar's quotation from John Marshall's pseudonymous defense of McCulloch v. Maryland. ${ }^{79}$ Marshall's essay there responds to attacks on McCulloch by Spencer Roane (writing as "Hampden"), who argued that the Court lacked jurisdiction to "adjudicate . . . away" the rights of the states. ${ }^{80}$ Marshall's response was simply that article III's "arising under" clause gave Congress power to confer appellate jurisdiction on the Supreme Court:

How does Hampden elucle this provision? Not by denying that the case "arises under the constitution." That, not even he can venture to deny. How ther does he elude it? He says that "these words may be otherwise abundantly satisfied."-But how "otherwise satisfied," he has not told us; nor can he. I admit there are other cases arising under the constitution. But the words are "all

and credit, but I would not have thought that a state court's ruling that the federal Constitution invalidates another state's law (a kind of vertical, federal/state question) inevitably implicates full faith and credit (which is typically a horizontal, state/state question). After all, the Missouri court's position-that a note issued in consideration of paper of the Bank of Kentucky was void, because the paper constituted bills of credit prohibiled by the federal Constitution-would have called for voiding a Missouri law authorizing issuance of such paper by a Missouri bank. The issue raised is not whether Missouri paid sufficient heed to Kentucky's law (as distinguished from some other state's law), but simply whether any state could constitutionally issue such paper. Beyond this, if Amar's characterization were valid, it would plug the gap in $\$ 25$ only in those cases in which state A's courts strike down the laws of state $B$ as federally invalid, leaving a gap in $\$ 25$ for the presumably more common cases in which state A's courts strike down state A's laws.

On a related point, Amar notes that Frankfurter and Landis "uncovered 'only" sixteen cases from 1789 to $1914 \ldots$ in which the section 25 'gap' was successfully invoked to defeat Supreme Court jurisdiction." Amar, supra note 6, at 1531 \& n.103 (citing F. FrankFurter \& J. LANDI:s, supra note 58 , at $190 \mathrm{n} .20$ ). If 16 cases constitute sparse authority (a dubious proposition), the proper lesson may be that few litigants tried to circumvent a basic and clearly established limit on the Supreme Court's jurisdiction.

77 Amar, Reply, supra note 9, at 1666-67.

78 See supra notes 33,76 ; infri note 228 .

79 I7 U.S. (4 Wheat.) 316 (1819).

80 John Marshall's Defense of McCulloch v. Maryland 138 (G. Gunther ed. 1969) (reprinting Essay of Hampden, Richmond Enquirer, June 22, 1819 (authored by Spencer Roane)). 
cases" and I deny that the word "some" can be substituted for "all," or that the word "all," can be satisfied if any one case can be withdrawn from the jurisdiction of the court. ${ }^{81}$

Marshall was clearly affirming that because article III extends to "all" cases arising under the Constitution, Congress does not lack power to assign the Supreme Court arising under jurisdiction in McCulloch or any other case-whether or not it has assigned other portions of the "arising under" jurisdiction in other cases. Even the language that on its face seems most favorable to Amar ("if any one case can be withdrawn from the jurisdiction of the court") merely criticizes Hampden's position, which "withdraw[s]" from the scope of the Supreme Court's jurisdiction under article III power to decide disputes (like $\mathrm{McCulloch}$ ) concerning the extent of national and state powers. Marshall had no occasion to argue that, had Congress not given the Supreme Court statutory jurisdiction to decide $\mathrm{McCulloch}$, article III would have been violated, and his words, read in context, carry no such suggestion.

Amar's treatment of this passage illustrates a more general point: the passages from Story and Marshall on which he relies are all extra-judicial expressions or dicta discussing situations in which Congress had given the federal courts jurisdiction in his mandatory tier. The testing case, however, is one in which Congress fails to provide jurisdiction in the mandatory tier. As I have just noted, Marshall and Story participated in four such cases, and each time enforced, without hesitation, a limitation on federal question jurisdiction.

\section{Admiralty Jurisdiction and the Saving to Suitors Clause}

A second possible gap arises under section 9 of the First Judiciary Act. ${ }^{82}$ This provision gives federal courts exclusive jurisdiction in admiralty, but saves "to suitors, in all cases, the right of a common law remedy, where the common law is competent to give it." The statute has come to mean that "to all intents and purposes every claim which can be enforced [in federal court] in admiralty by an in personam libel can be enforced in state courts [under the "saving to suitors" clause] . . . by action in personam." 83 If a plaintiff chooses

81 Id. at 212 (reprinting Essay by A Friend of the Constitution, Alexandria Gazette, July 15, 1819 (authored by John Marshall)).

82 Judiciary Act of 1789 , ch. $20, \S 9,1$ Stat. 73, 76-77.

83 Black, Admiralty Jurisdiction: Critique and Suggestions, 50 Colum. L. Rev. 259, 265 (1950); see also New Jersey Steam Navigation Co. v. Merchant's Bank, 47 U.S. (6 How.) 344, 389-90 (1848); Waring v. Clarke, 46 U.S. (5 How.) 441, 461 (1847). See 
the state forum, the defendant may not remove, and in many casesparticularly before the twentieth century, but even thereafter-there would be no Supreme Court review. ${ }^{84}$

This jurisdictional arrangement raises the question whether the cases filed in state court under the savings clause are cases of "admiralty and maritime" jurisdiction within the meaning of article III. If so, the First Judiciary Act included another gap in Amar's mandatory tier. Amar argues, however, that these state law actions are by definition not admiralty cases, and notes that the procedural and substantive rules governing an in personam action varied depending on whether it was filed "in admiralty" or "at common law." 85 According to this view, what is involved is not the description a-modern lawyer would provide of concurrent state and federal jurisdiction over a single action, but rather an understanding that a particular transaction could support two quite different kinds of actions-one in admiralty and one at common law. The law and chancery courts would not have been viewed as having concurrent jurisdiction over the same case when a suitor might seek either damages or restitution; rather, each had exclusive jurisdiction over particular remedies. So, too, with admiralty and common law courts. ${ }^{86}$

generally G. Gilmore \& C. Black, The Law of Admiralty § 1-13, at 37-40 (2d ed. 1975); D. RoBERTSON, supra note $\$ 0$, at 18-19, 27, 123-25.

84 For more than a century, the governing law applied by state courts in maritime actions was not conceived of as federal admiralty law. See, e.g., G. GiLmore \& C. BLACK, supra note 83, § 1-16, at 45; Currie, Federalism and the Admiralty: The Devil's Own Mess, 1960 Sup. CT. Rev. 158, 159; Fletcher, The General Common Law and Section 34 of the Judiciary Act of 1789: The Example of Marine Insurance, 97 HaRv. L. REv. 1513, 1550-53 (1984). Though the Supreme Court could review state court decisions to determine whether they fell within the scope of the savings clause or whether they conflicted with a federal statute, see, e.g., Sherlock v. Alling, 93 U.S. 99, 101-04 (1876), there was no general review of state common law maritime decisions.

Southern Pacific Co. v. Jensert, 244 U.S. 205, 215-17 (1917), and Chelentis v. Luckenbach S.S. Co., 247 U.S. 372, 383-84 (1918), gave rise to a view of admiralty as "a uniform body of substantive federal law applicable not only in admiralty courts but also in the state courts and on the 'law side' of federal courts." HaRT \& WECHSLER, supra note 2, at 892 . But there have remained important limits on the uniformity doctrine, see, e.g., Wilburn Boat Co. v. Fireman's Fund Ins. Co., 348 U.S. 310, 316-19 (1955); D. ROBERTSON, supra note 30, at 145-47, and even today the Supreme Court lacks plenary authority to review a state court's legal and factual determinations in cases heard under the saving to suitors clause.

85 See G. GILMORE \& C. BlaCk, supra note 83, § 1-9, at 19, § 1-13, at 37.

86 Amar properly notes the uncertainty about the meaning of "maritime" in the specification of "admiralty and maritime jurisdiction." To the extent that that phrase extended beyond admiralty cases traditionally understood, it is more difficult for him to argue that cases filed under the "saving to suitors" clause clearly fall outside of the federal judicial power. But though the addition of the word "maritime" may have been meant to "guard against any narrow interpretation of the preceding word, 
I think Amar's argument is a plausible one, but I would raise two questions about it. The first is why mandatory federal jurisdiction is unimportant in common law maritime matters. As Justice Story himself recognized in both Martin and in his commentaries, ${ }^{87}$ prototypical in personam suits like maritime tort and contract actions may well implicate the concerns underlying federal jurisdiction in admiralty, as these suits involve national policy, the rights and duties of foreigners, intercourse with foreign states, and the law of nations. ${ }^{88}$ The presence of those concerns does not necessarily depend on whether the plaintiff chooses to frame his complaint in admiralty or at common law. But this response is a characteristically modern, functional argument, and two centuries ago a more conceptual vision may have prevailed.

The second question goes to the wording of the First Judiciary Act. If the conceptual view on which Amar relies was so entirely clear, one might ask why the savings clause was even necessary, for on Amar's account, an eighteenth century lawyer would not have imagined that giving the federal courts exclusive power to entertain "civil causes of admiralty and maritime jurisdiction" in any way limited the state courts from entertaining a wholly different animal, the suit at common law. But statutory redundancy for purposes of emphasis is hardly unknown, as I noted earlier. ${ }^{89}$

In the end, Amar does seem to me to have presented a coherent, if not entirely unproblematic, argument that the saving to suitors clause is consistent with his thesis.

\section{Jurisdiction Affecting Ambassadors}

Amar concedes that section 13 of the First Judiciary Act does not fully vest article III's jurisdiction affecting ambassadors and other diplomats. ${ }^{90}$ His response is simply to observe, correctly, that that

'admiralty," " $3 \mathrm{~J}$. STORY, supra note $5, \S 1666$, at 527; see also Black, supra note 83, at 262 n.12 (maritime added to assure that jurisdiction was not limited in the same manner as was that of colonial vice-admiralty courts), the terms "admiralty" and maritime are traditionally understood to be synonymous in this context, see $\mathbf{G}$. GiLMORE \& C. BLACK, supra note 83, § 1-1, at 1 .

87 See Martin v. Hunter's Lessee, 14 U.S. (1 Wheat.) 304, 335 (1816); 3 J. SToRx, supra note 5, $\S \S 1663-65$, at 530-33. But cf. id. $\S 1666$, at 533 \& n.3 (exclusive federal jurisdiction necessary in prize cases but not necessarily in "many" other maritime cases in which common law courts are competent to provide remedies).

88 See 3 Elitot's Debates, supra note 5, at 532 (remarks of James Madison).

89 See supra text accompanying notes 17-23.

90 See Amar, supra note 6, at 1522. Article III authorizes jurisdiction in "all cases affecting Ambassadors, other public Ministers and Consuls." U.S. ConsT. art. III, § 2 
gap is also problematic for traditionalists, though for a different reason. The ambassador jurisdiction is part of the Supreme Court's original jurisdiction, which, most traditionalists believe, Congress cannot limit. ${ }^{91}$ Hence, there is a gap not only in Amar's mandatory tier but also in the original jurisdiction.

Amar proceeds to argue that the gap is more embarrassing for traditionalists than it is for him. ${ }^{92}$ If the original jurisdiction is mandatory, it must be, Amar says, because article III says that the Supreme Court "shall have original Jurisdiction" over the designated cases. But, he continues, if "shall" is mandatory here, it must be mandatory elsewhere in article III-just what traditionalists deny. ${ }^{93}$

Comparative embarrassment is rather difficult to calibrate, but one could plausibly argue just the opposite. Amar's claim that the traditionalists offer inconsistent conclusions about whether the word "shall" is mandatory loses force because of the different phrases and contexts in which "shall" appears in article III. One can easily read "the judicial Power shall extend" as referring only to matters over which the federal courts have capability (rather than an obligation),

(emphasis added). Section 13 of the First Judiciary Act gave the Supreme Court exclusive jurisdiction in suits against ambassadors, other public ministers, or their domestics or domestic servants, and concurrent jurisdiction of all suits brought by ambassadors, or other public ministers, or in which a consul or vice consul shall be a party. See Judiciary Act of 1789, ch. 20, § 13, 1 Stat. 73, 80-81. Section 13's gaps are twofold. First, it gave jurisdiction only where diplomats or their domestics are parties; these cases, however, are presumably only a subset of cases affecting diplomats, for otherwise Congress would likely have used the clearer and narrower definition. See Osborn v. Bank of the United States, 22 U.S. (9 Wheat.) 738, 855 (1824). But $f$. United States v. Ortega, 24 U.S. (11 Wheat.) 467, 468 (1826) (prosecution for offering violence to the person of a foreign minister was not a case "affecting" the minister). Second, if suits against domestics fall within article III, presumably suits by domestics (not mentioned in $\S 13$ ) do as well. In addition, suits brought by (rather than against) consuls or vice-consuls could be filed in state court, see Judiciary Act of 1789 , ch. $20, \S 9,1$ Stat. 73, 76-77, with no provision for removal or review. See also infra notes 124, 130, 138.

91 See, e.g., Redish, Power To Kegulate, supra note 2, at 901. Henry Hart is not strictly a traditionalist, as he suggested that Congress's power over the Supreme Court's appellate jurisdiction might not be unbridled, but he too thought the original jurisdiction was mandatory. See Hart, supra note 2, at 1372-73.

A letter from Oliver Ellsworth (signed A Landholder) stated: "[N]othing hinders ... that all the cases, except the few in which it [the Supreme Court] has original and not appellate jurisdiction, may in the first instance be had in the state courts . ..." Essays on the Constitution of the Unired States 164 (P. Ford ed. 1892) [hereinafter EsSAYS ON THE Consmiution] (reprinting Letter to Landholders and Farmers from A Landholder (VI), Conn. Courant, Dec. 10, 1787).

92 See Amar, supra note 6, at 1524-25.

93 Id. 
and the "judicial Power ... shall be vested in" as referring to the courts that may (rather than must) exercise that capability.

By contrast, the phrase "shall have original Jurisdiction" has a more imperative ring, particularly when the context is considered. This language appears in a paragraph distinguishing between the Supreme Court's original and appellate jurisdiction. Article III expressly made the appellate jurisdiction subject to Congress's power to make exceptions, but gives no such power to limit the original jurisdiction. ${ }^{94}$ The mandatory quality of the phrase "shall have original Jurisdiction" is thus supported by the absence of congressional power to make exceptions to the original jurisdiction.

If the traditionalist view is not as infirm as Amar suggests, his own view poses some serious difficulties. Unlike traditionalists, who posit that both categories of original jurisdiction are mandatory, Amar distinguishes between them. Only the ambassador jurisdiction is mandatory, while the state as party jurisdiction could, he says, be left to the state courts entirely. The First Judiciary Act, however, points in just the opposite direction. It has gaps in the ambassador jurisdiction, ${ }^{95}$ but it fully vests the Supreme Court's original jurisdiction (at least concurrently) when a state is a party. ${ }^{96}$ And in debate on the Act, Representative Stone said:

94 Article III provides:

In all Cases affecting Ambassadors, other public Ministers and Consuls, and those in which a State shall be a Party, the supreme Court shall have original Jurisdiction. In all the other Cases before mentioned, the supreme Court shall have appellate Jurisdiction, both as to Law and Fact, with such Exceptions, and under such Regulations as the Congress shall make.

U.S. Const. art III, $\S 2$.

95 See supra note 90 and accompanying text.

96 See Judiciary Act of 1789 , ch. 20, \& 13, 1 Stat. 73, 80-81. Section 13 excludes cases between a state and its citizens, but the Supreme Court seems clearly correct in having interpreted article III's grant of original jurisdiction where the state is a party as referring only to cases otherwise within the judicial power. See Pennsylvania v. Quicksilver Co., 77 U.S. (10 Wall.) 553, 556 (1871). More difficult is the question whether the jurisdiction extends to cases that are within the judicial power, but not by virtue of the fact that the state is a party-as might be true of federal question cases or cases in which the United States is a party. The court declined jurisdiction in the first situation, see California v. Southern Pacific Co., 157 U.S. 229, 257-62 (1895), but accepted it in the second, see United States v. Texas, 143 U.S. 621 (1892).

That the jurisdiction is concurrent only, with no removal to the Supreme Court authorized should plaintiff file in a different forum, is hardly unproblematic. See infra note 138.

The Court's present day original jurisdiction over cases in which a state is a party does have one gap: unlike article III, it does not include cases between a state and a foreign government. See 28 U.S.C. § 1251 (1982). To my knowledge, no such suit 
I apprehend in every thing else the State courts might have had complete and adequate jurisdiction; the State courts could not determine between State and State, because their judgment would be ineffectual; they could never carry it into execution. But I apprehend in all other cases the States could execute that authority which is reposed in the United States."97

The Act and its history thus seem at least as hard to square with Amar's position as with the conventional one. ${ }^{98}$

Amar adds that "one would be hard pressed indeed to develop strong structural reasons for seeing all cases in the Supreme Court's original jurisdiction as qualitatively more important than all cases in its appellate jurisdiction."99 I am quite satisfied, however, with the traditional explanation for the original jurisdiction: that federal jurisdiction over another sovereign ${ }^{100}$ is so sensitive that only the court of greatest dignity should exercise it. ${ }^{101}$ Indeed, it is worth

has ever been filed in the Supreme Court, and if it were, the Court would presumably have jurisdiction only if the defendant consented. See 3 Elliot's DEBaTES, supra note $\mathbf{5}$, at 533 (remarks of James Madison); id. at 557 (remarks of John Marshall). If that situation ever arose, the Supreme Court might be required to hold $\S 1251$ unconstitutional.

97 Annals of Cong., supra note 14 , at $840-41$; see also id. at 825 ; text accompanying notes $44-47$.

Similar views were expressed in the ratification debates. The essayist "Candidus," thought to be Samuel Adams or his follower, Benjamin Austin, Jr., wished to exclude federal question cases from Supreme Court jurisdiction, confining it instead to matters affecting more than one sovereign-cases under treaties, the ambassador jurisdiction, controversies between two states, or involving two states' conflicting land grants, admiralty jurisdiction, and offenses against the law of nations. See 4 H. Storing, supra note 19, at 131-32.

98 See also infra notes 124, 1.38 (discussing the significance of the original jurisdiction's being concurrent in many instances).

Amar suggests that the First Judiciary Act cannot be more embarrassing to his view of the original jurisdiction than to the traditional view. He properly notes that any gap in the ambassador jurisdiclion embarrasses both views, but gaps in the state as party jurisdiction embarrasses only traditionalists. See Amar, supra note 6, 1525 n.80. He is surely right that it is easier to satisfy a single condition than to satisfy a second one as well. But it is particularly awkward for his argument that the Act had gaps in the portion of the original jurisdiction that he claims is mandatory, but not in the portion that he claims is non-mandatory.

99 Amar, supra note 6, at 1523 .

100 In the case of the ambassador jurisdiction, jurisdiction that affects another sovereign through its diplomatic representatives is vested in the Supreme Court. $C f$. Davis v. Packard, 32 U.S. (7 Pet.) 276 (1833) (failure to plead consular status in state court not waived, because privilege belongs to the foreign government rather than to the official personally).

101 See, e.g., California v. Arizona, 440 U.S. 59, 65-66 (1979); Ames v. Kansas, 111 U.S. 449, 464 (1884); The Fejeralist No. 81, supra note 30, at 511; HarT \& WECHSLER, supra note 2, at 296; 3 J. STORY, supra note 5, § 1654, at 522-23. 
recalling that admiralty jurisdiction-the least controversial component of the federal judicial power-was thought necessary because maritime matters were viewed as part of the law of nations, and frequently affected foreign sovereigns. As for the sensitivity of cases involving the states, we need only recall that the Supreme Court's exercise of original jurisdiction in 1793 in Chisholm v. Georgia ${ }^{102}$ promptly led to adoption of the eleventh amendment, which restricted the federal courts' power to adjudicate suits against sovereign states. ${ }^{103}$

\section{B. The Legislative History of the First Judiciary Act}

The passage from Hart $\mathcal{E}$ Wechsler quoted earlier questioned whether the debate over the First Judiciary Act recognized any distinction between Amar's two tiers. ${ }^{104}$ I turn next to Amar's claim that those debates contain "considerable historical support for the thesis." 105

\section{General Observations}

Amar highlights several aspects of these debates: (i) some representatives urged their colleagues, when passing a statute establishing the entire federal judiciary, to view the matter as a whole; ${ }^{106}$ (ii) Representative Smith observed that the creation of lower courts might limit the number of appeals from the state courts that the Supreme Court would otherwise hear; ${ }^{107}$ (iii) many statesmen urged that the federal courts' power be coextensive with the scope of federal law; ${ }^{108}$ (iv) several comments emphasized the importance of federal question jurisdiction; ${ }^{109}$ and (v) some in Congress were wary of relying

1022 U.S. (2 Dall.) 419, 431 (1793).

103 One need not accept the traditional state sovereignty theory of the eleventh amendment in making this point. See Hans v. Louisiana, 134 U.S. 1 (1890). The amendment's diversity explanation, expressed in Atascadero State Hosp. v. Scanlon, 473 U.S. 234, 247-302 (1985) (Brennan, J., dissenting), which both Amar and I find persuasive, see Amar, Of Sovereignty and Federalism, 96 YALE L.J. 1425, 1481-84 (1987) [hereinafter Amar, Sovereignty], is also consistent with recognition of states as having special sovereign status. For a lucid and helpful summary and discussion, see Fletcher, The Diversity Explanation of the Eleventh Amendment: A Reply to Critics, $56 \mathrm{U}$. CHr. L. Rev. 1261 (1989).

104 See supra text accompanying note 13.

105 Amar, supra note 6, at 1547.

106 See id. at 1547-48.

107 See id. at 1559-60; see also infra text accompanying notes 126-28.

108 See Amar, supra note 6, at 1563-65. Amar repeatedly emphasizes the “coextensiveness principle" in his article. See, e.g., id. at 1511-12, 1539, 1557.

109 See id. at 1548-53, 1557-59. 
too heavily on the organs of state government. ${ }^{110}$ Amar argues, correctly, that these views are consistent with his thesis.

The difficulty, however, is that they are equally consistent with an entirely non-mandatory view of article III, for each statement can easily be read as a policy argument about how Congress's broad constitutional prerogative ought to be exercised. These statements do not undercut Amar's thesis, but they do not support it.

\section{Specific Evidence}

Amar's more specific efforts to find support in the debates for the two-tier thesis rely heavily on the statements of Representative Smith and Senator Maclay in the first Congress. ${ }^{111}$ Both men, however, misunderstood article III as precluding state courts from hearing any cases within the federal judicial power. ${ }^{12}$ Holding that view, it is not surprising that they thought Congress was obliged to vest jurisdiction in the "inferior" federal courts. ${ }^{113}$

Unlike Amar, ${ }^{114}$ I do not think that basic misconception can be severed from their mandatory reading of the "shall be vested" language. If the state courts could not hear any of the cases described in article III, then Congress's failure to vest jurisdiction in the inferior federal courts would preclude any adjudication of these cases (except those few falling within the Supreme Court's original jurisdiction)-a far more serious matter than leaving various categories to the state courts for adjudication.

As for the two-tier thesis, Smith mentions the word "all" once, in the following passage discussing a proposal to limit lower federal court jurisdiction to admiralty cases:

110 See id. at 1565.

111 See id. at 1548-54.

112 See ANNAls of Cong., supriz note 14, at 819 (remarks of Rep. Smith) ("[T]he Constitution, in the plainest and most unequivocal language, preclude[s] us from allotting any part of the Judicial authority of the Union to the State judicature."); 9

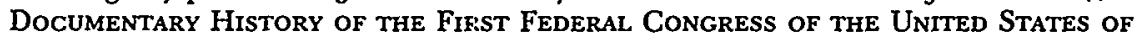
AMERICA 87 (K. Bowling \& H. Veit eds. 1988) (reprinting The Diary of William Maclay) [hereinafter Diary of William Maclay]. Smith also appears to have believed that the Supreme Court's appellate jurisdiction was limited to reviewing federal, and not state court, decisions. See ANNAl.s of Cong., supra note 14, at 818 . But cf. id. at 819 (If a state court usurps a federal court's exclusive jurisdiction, the "National tribunal" must possess power to protect the Union's rights.).

113 See AnNals of Cong., supra note 14, at 801, 817; Diary of William Maclay, supra note 112, at 87; see also Casto, supra note 55, at 1110 n.70. Others in the first Congress, however, expressed the opposite view. See supra note 15.

114 See Amar, supra note 6, at 1553. 
It is declared by [article III] that the judicial power of the United States shall be vested in one supreme, and in such inferior courts as Congress shall from time to time establish. Here is no discretion, then, in Congress to vest the judicial power of the United States in any other than the Supreme Court and the inferior courts of the United States. It is further declared that the judicial power of the United States shall extend to all cases of a particular description. How is that power to be administered? Undoubtedly by the tribunals of the United States; if the judicial power of the United States extends to those specified cases, it follows indisputably that the tribunals of the United States must likewise extend to them ... . [Congress cannot] assign the jurisdiction of some of these very cases to the State courts .... ${ }^{115}$

Smith does not clearly distinguish among the nine heads of jurisdiction, or recognize that "all" modifies only some of them. Moreover, earlier that day in the same debate, he stated (without distinguishing subject-matter from party-based jurisdiction) that "those causes which, by the Constitution are declared to belong to the judicial courts of the United States," cannot be left exclusively to state court determination. ${ }^{116}$ In the considerable discussion that ensued, no other representative mentioned the distinction that Amar finds in Smith's comments. All in all, I think it more plausible to read Smith as suggesting that the whole judicial power, and not just Amar's firsttier, must be vested in the federal courts. ${ }^{117}$

Much the same is true of Senator Maclay. Amar quotes this excerpt from his diaries: "But the Constitution expressly extended [federal jurisdiction] to all cases in law and equity under the Constitution[,] the Laws of the united States, Treaties made or to be made. \&ca." "18 The notation "\&ca." is profoundly ambiguous; does it refer only to the subject matter clauses, or to the entire judicial power? Maclay's entry the following day seems to support the latter reading. He wrote: "[I]f any matter made cognizable in a federal Court, should be agitated in a State Court, a plea to the Jurisdiction would immediately be put in, and proceedings would be stayed." 119 This entry, to be sure, follows a discussion of federal question jurisdiction; it could, but need not, be read as referring only to those cases. On balance, however, it seems that Maclay, like Smith, did not clearly

\footnotetext{
115 Annals of Cong., supra note 14, at 801 (emphasis added).

116 Id. at 798.

117 See Clinton, Early Implementation, supra note 6, at 1534-40.

118 Diary of William Maclay, supra note 112 , at 85 . -

119 Id. at 87.
} 
articulate the distinction on: which Amar rests, if he articulated it at all. ${ }^{120}$

In sum, the historical grounding for the two-tier thesis in the provisions of, and debates surrounding, the First Judiciary Act seems to me shaky at best.

\section{Mandatory Vestinc: and the Supreme Court's Original JURISDICTION}

Having mentioned the Supreme Court's original jurisdiction, I would like to explore more generally how Amar understands article III's assignment of two categories of cases to the Supreme Court for trial. This question is not a detour from consideration of Amar's two-tier thesis. Amar contends that a proper understanding of the original jurisdiction reinforces his thesis. ${ }^{121}$ The traditional view of the original jurisdiction, however, poses a difficulty for Amar. The original jurisdiction extends not only to cases affecting ambassadors but also to cases in which a state is a party. Thus, under the traditional view of the original jurisdiction as mandatory, article III requires the federal judiciary' (more specifically, the Supreme Court) to exercise jurisdiction over some party-based cases-cases that, under Amar's view, fall within the non-mandatory tier.

Not surprisingly, Amar rejects the view that the original jurisdiction is itself mandatory. Instead, following his two-tier thesis, Amar contends that the original jurisdiction in cases affecting ambassadors, because it is modified by the word "all," has to be vested in the

120 Amar also finds "modest" additional support in a passage in the notes of Senator William Paterson, which reads, somewhat cryptically: "The Constn. points out a Number of Articles, which the federal Courts must take up." See Amar, supra note 6, at 1554-55. Amar interprets this language as suggesting that his first-tier is mandatory, while Professor Casto reads it as suggesting that the original jurisdiction is mandatory. See Casto, supra note 55, at 1108 n.56.

Neither interpretation is wholly implausible. If I wished to take issue with Amar, I would point out that (i) the next sentence in the notes reads, "The objects are not different-they legislate upon Persons and Things," id. at 1132, which might be understood as undercutting a distinction between subject-matter and party-based heads of jurisdiction; (ii) Patersori's arguments seem to focus on questions of expediency, not constitutionality, see id. at 1138; and (iii) Paterson employs categories (for example, federal crimes and federal revenue cases) not congruent with article III, see id. at 1129. More importantly, however, the obscurity of this fragment (apparently made in preparation for a speech, see id. at 1127, 1133), and the absence of a comparable passage in the notes of the speech itself, see id. at 1133-35, make it rather thin support for Amar.

121 See Amar, supra note 6, at 1522-25. 
federal judiciary, while the state-as-party jurisdiction, which is not similarly modified, does not. ${ }^{122}$

But why is either of these two categories singled out, from among all of the heads of jurisdiction in article III for trial in the Supreme Court? Amar places heavy emphasis, in this and in an earlier article, on a geographical explanation for the original jurisdiction: cases affecting ambassadors, and any state-as-party cases that Congress may designate for federal adjudication, must be triable in the Supreme Court because it will, presumably, be located in the nation's seat of government. ${ }^{123}$ (I use the word "triable" because Amar would permit the Supreme Court's original jurisdiction to be concurrent with the inferior federal courts, so long as the defendant could remove from an inferior court to the Supreme Court.) ${ }^{124}$

122 See Amar, Original Jurisdiction, supra note 1, at 479-80. He again invokes Justice Story, quoting the first of the following three sentences from his opinion in Martin:

It is declared that "in all cases affecting ambassadors, \&cc., that the supreme court shall have original jurisdiction." Could congress withhold original jurisdiction in these cases from the supreme court? The clause proceeds-"in all the other cases before mentioned the supreme court shall have appellate jurisdiction, both as to law and fact, with such exceptions, and under such regulations, as the congress shall make."

Martin v. Hunter's Lessee, 14 U.S. (Wheat.) 304, 332 (1816), quoted in Amar, Original Jurisdiction, supra note 1 , at 485 . Amar suggests that notwithstanding the "\&cc.," the first sentence refers only to ambassador cases, not to state as party cases. But the third sentence-"the clause proceeds"-suggests that Story's first sentence referred to the entire first sentence of the second paragraph of article III, $\S 2$ (which includes the state-as-party jurisdiction), while Story's third sentence referred to the immediately subsequent language in § 2: "In all other cases ...." See supra note 94 (quoting the pertinent language from article III). Thus, to me, at least, Story's views about original jurisdiction are more in line with the traditionalists than with Amar. See also Sager, supra note 3, at 24.

123 See Amar, Original Jurisdiction, supra note 1, at 479-80; Amar, supra note 6, at 1559-62.

124 See Amar, Original Jurisdiction, supra note 1, at 487 n.204, 492 n.219; Amar, Neo-Federalist View, supra note 1 , at $261 \mathrm{n} .183$. Thus, no case within the original jurisdiction could be finally resolved by a lower federal court unless both parties accepted the concurrent forum. See supra note 7.

Amar recognizes that the First Judiciary Act provided for concurrent jurisdiction in the lower federal courts in some ambassador cases without expressly authorizing removal to the Supreme Court. That arrangement, he suggests, may itself have been unconstitutional unless the Supreme Court were viewed as having removal jurisdiction under article III itself, as supplemented by $\S 14$ of the First Judiciary Act, see Judiciary Act of 1789 , ch. 20, $\$ 14,1$ Stat. 73, 81-82 (the original version of today's All Writs Act, 28 U.S.C. $\$ 1651$ (1982)). See Amar, Original Jurisdiction, supra note 1, at 492 n.219.

One further qualification is necessary in describing Amar's views. Under the First Judiciary Act, suits brought by foreign diplomats were not in the exclusive federal jurisdiction, and if filed in state court, there was no express provision for 
One could respond to Amar's geographical explanation by asking: Why didn't the framers just include a venue provision limiting suit to any federal court sitting in the seat of government, rather than confining adjudication to the Supreme Court? Article III, after all, does include venue provisions governing criminal prosecutions. ${ }^{125}$ Beyond that perhaps too easy rejoinder, Amar's evidence that the original jurisdiction had an important geographical basis seems a bit weak.

Amar cites evidence, in the ratification debates, of considerable concern that the Supreme Court, distant from the outer reaches of the nation, might prove to be an inconvenient forum. To me, however, the pertinent question is not simply whether the framers were concerned about convenience. It is, rather, whether there is any evidence that anyone viewed the Supreme Court as being more, rather than less, convenient as a trial forum for cases in the original jurisdiction. On that score, eviclence is lacking-though, as Amar properly notes, in general the evidence about original jurisdiction is scanty. ${ }^{126}$

removal. See Judiciary Act of 1789 , ch. $20, \S \S 9,13,1$ Stat. 73, 76-77, 80-81. He concedes that this arrangement conflicts with his theory of mandatory vesting, but suggests (without endorsing the view) that the first Congress may have understood the ambassador jurisdiction as designed to protect diplomats, a protection they could waive by filing in state court. See Amar, Neo-Federalist View, supra note 1, at $261 \mathrm{n} .183$; infra note 130 .

125 See U.S. Const. art. III, § 2, cl. 3.

126 Amar, supra note 6, at 1561) n.222. Amar speculates that the Supreme Court was an appropriate forum, or at least a less inappropriate forum, in ambassador cases because it would be geographically convenient for foreign dignitaries who had been received by the President in the seat of government, and who could communicate promptly with executive officials about late-breaking developments. See Amar, Original Jurisdiction, supra note 1 , at 476 . This suggestion is ingenious, if not evidenced in any contemporary sources, but one is again tempted to ask why a venue requirement would not serve the same purpose. Moreover, consuls were expected to reside outside of the capital, see infra note 129, making the Supreme Court a particularly inconvenient forum. As Chief Justice Taney explained:

It could hardly have been the intention of the statesmen who framed our constitution, to require that one of our citizens who had a petty claim of even less than five dollars against another citizen, who had been clothed by some foreign government with the consular office, should be compelled to go into the supreme court to have a jury summoned in order to enable him to recover it ....

Gittings v. Crawford, 10 F. Cas. 447, 451 (C.C.D. Md. 1838) (No. 5,465). Though article II, § 3, states that the President "shall receive Ambassadors and other public Ministers" but not consuls, perhaps because the last were expected to reside throughout the nation, article III's grant of original jurisdiction does not distinguish between consuls and other foreign officials.

For controversies to which a state is a party, litigation in the capital would also be 
Amar's other evidence for his "geographic" theory is the concern expressed, in the debates over the First Judiciary Act, about the possible inconvenience resulting from federal jurisdiction. There were objections to the exercise of diversity jurisdiction over non-citizen defendants; Maine was included in the nearby federal district for New Hampshire rather than in that for Massachusetts, of which Maine was then a part; the vicinage principle in criminal prosecutions was protected. ${ }^{127}$ All of this evidence, however, pertains to these quite different matters, not to the Supreme Court's original jurisdiction. And it is hardly remarkable that Congress was attentive to questions of convenience when constructing the national judiciary. ${ }^{128}$

Quite apart from its uncertain historical foundation, the geographical theory seems to me to lack explanatory power. Consider first the ambassador jurisdiction. Suppose a foreign consul living in Boston had business dealings that gave rise to litigation between him

convenient, Amar suggests, as each state would have legislative representatives "who could be relied on to attend to the state's litigation interests." Amar, Original Jurisdiction, supra note 1 , at 476 . His observation that federal legislators played notable roles in a number of notable cases, see Amar, supra note 6, at $1560 \mathrm{n}$. 222-even if strengthened to show that in a large percentage of original jurisdiction cases, a state was represented (or attended to) by one of its legislators-may confuse the reason for the original jurisdiction with its effect. Once that jurisdiction was established, a state may have found in many cases that there was no more convenient arrangement for representation than reliance on its legislators. That evidence does not show, however, that the original jurisdiction was established because the framers thought litigation before the Supreme Court was expected to be so convenient that Congress should be precluded from assigning the cases exclusively to any other federal court. Indeed, in a dispute between Massachusetts and a Connecticut citizen, it seems very doubtful that litigation in the capital (away from the witnesses, state government officials, and many of the most likely counsel) was obviously more convenient than in a federal court closer to home-perhaps one in Rhode Island if those in Massachusetts or Connecticut were not sufficiently impartial. See also infra note 138.

127 See Amar, supra note 6, at 1559-63 \& n.223 (citing J. GoEbel, History of THE Supreme Court of the UnIted STates: ANTEcedents and Beginnings to 1801, at $460,471,497,500,507$ (1971)).

128 Amar's geographic explanation of the original jurisdiction does not seem to be advanced by his observation that some of the framers defended the circuit court's jurisdiction as reducing the number of appeals from state courts that the Supreme Court would have to entertain, see Amar, Original Jurisdiction, supra note 1, at 471-72; see also infra note 181, and that William Paterson noted the greater convenience of relying not on the Supreme Court alone but on lower federal courts distributed throughout the states, see Amar, supra note 6, at 1559-60. Again, it seems quite unexceptional that the first Congress would have tried to make the federal judiciary a convenient mechanism. That inferior court trial jurisdiction might prove more convenient than Supreme Court appellate jurisdiction hardly shows that article III established the Supreme Court's original jurisdiction for geographic reasons. 
and a Massachusetts citizen. ${ }^{129}$ Amar suggests that although the lower federal courts could not exercise exclusive jurisdiction over the suit, they could be given jurisdiction that was concurrent with the Supreme Court. At least if the public consul so chose, ${ }^{130}$ suit would have to be in the Supreme Court-even if both parties and all the evidence resided in Massachusetts. Particularly under eighteenth century transportation conditions, the Supreme Court would be a far less convenient forum than a lower federal court in Massachusetts.

Next, consider the jurisdiction where a state is a party. Here, Amar uses the example of suits between two states. He is surely right that if a lower federal court tried to resolve such a dispute, "[o]ne of the two states would enjoy an unseemly 'home field' advantage."131 But this concern about home field advantage would seem to be as forceful in other cases outside of the Supreme Court's original jurisdiction: for example, a suit in lower federal court in Massachusetts involving a conflict between Massachusetts and Connecticut land grants (whether or not both litigants were citizens of Massachusetts). ${ }^{132}$ Indeed, his concern would be most sharply implicated if the Commonwealth of Massachusetts tried to sue the State of Connecticut in Massachusetts state court. ${ }^{133}$ But Amar reads article III as permitting such a suit, because disputes between two states are not within his mandatory tier. The concern about home field advantage thus does not provide a coherent explanation for the results reached under Amar's account.

129 There is little doubt that consuls were expected to reside outside of the seat of government. See, e.g., $5 \mathrm{~J}$. Moore, A Digest OF InTERnational Law $\$ 700$, at 19 (1906); 7 Treaties and Other InTERnational AgreEments of the UNITEd STATES of AMERICA, 1776-1949, at 773 (C. Bevans ed. 1968); Johnson, The Early History of the United States Consular Service. 1776-1792., 13 PoL. Sci. Q. 19, 26-27 (1898). I thank Detlev Vagis for leading me to these sources.

130 Amar hints at the possibility that the ambassador jurisdiction could be viewed as protecting diplomats only, and hence waivable by them if they preferred to sue in state court. See supra note 124. But this view (which Amar sketches without endorsing) poses some difficulties. It is hard to affirm that the Supreme Court was given original jurisdiction for venue reasons when, as in the example posed in the text, that forum was obviously less convenient for both parties, even if the diplomat might prefer it for strategic reasons (as when his resources far exceeded those of his adversary). In the ratification debates, anti-federalist writers objected to the original jurisdiction over diplomats because of its possible inconvenience for their adversaries. See, e.g., 2 H. Storing, supra note 19, at 69, 431.

131 Amar, Original Jurisdiction, silpra note 1, at 477.

132 See 2 Ellot's Debates, supra note 5, at 481 (remarks of James Wilson); 3 id. at 523 (remarks of George Mason); 4 id. at 159 (remarks of William Davie); $3 \mathrm{~J}$. STORY, supra note $5, \S 1690$, at 567 .

133 See supra text accompanying notes $44-47$. 
Moreover, the original jurisdiction extends to numerous cases in which only one party is a state. ${ }^{134}$ If I understand Amar's view, Congress could not assign a suit by the state of Massachusetts against a Connecticut citizen, or against an alien, exclusively to a lower court in Massachusetts. Because only the Supreme Court would constitute a neutral federal tribunal, each side could insist that the Court try the dispute. ${ }^{135}$ But Amar also argues that Congress is free to refuse to vest jurisdiction in the federal judiciary at all, leaving the suit to be heard in a Massachusetts state court, without any federal review, even over the individual defendant's objection. That pair of results seems quite puzzling under a venue-based theory, ${ }^{136}$ and create ten-

134 Amar suggests that insofar as cases in which the state is a party are today viewed as particularly momentous, it is "because those cases do often involve important constitutional issues." Amar, Original Jurisdiction, supra note 1 , at 486 . The point has some force, given the enactment of the Bill of Rights and the fourteenth amendment, and the subsequent incorporation of nearly all of the amendments in the Bill of Rights (though the eleventh amendment, of course, limits suits nominally against states). But in 1787 or 1789 , a more typical suit would, I suspect, have been a debt action against a state, like Chisolm v. Georgia, 2 U.S. (2 Dall.) 419 (1793), or a suit involving disputes about real property. See also $4 \mathrm{H}$. STORING, supra note 19 , at 78 (Letter of Agrippa). These suits were thought to be important by the framers for quite different reasons.

135 See Amar, Original Jurisdiction, supra note 1, at 492 n.219.

196 A possible response to the anomaly is that article III is more concerned with the integrity and fairness of federal courts than of state courts. Indeed, a similar argument is sometimes made in explaining why article III's tenure and salary protection does not extend to state court judges. See Fallon, Of Legislative Courts, Administrative Agencies, and Article III, 101 HARv. L. REv. 915, 941 (1988) ("In a federal system, there is no anomaly in the national Constitution's setting a higher standard for the courts of the national government than it imposes on state courts."). Amar clearly rejects the argument that the salary and tenure clause has this conditional "if and when" quality, for such a position would conflict with a number of his structural principles-most notably his argument that federal adjudication must be coextensive with the scope of federal law. See infra text accompanying notes 164-69. He asserts, however, that "home field advantage" is of concern only "if and when" the federal courts hear the case. See infra text accompanying notes 173-76.

I understand his position, though I think it suffers from some difficulties. The most striking question, as just noted in the text, is why the framers would have been so concerned about federal court venue as to constitutionalize it, while being utterly indifferent to the stronger home-field advantage of state courts. And I have trouble reading the statements of eighteenth century statesmen in support of the state-asparty jurisdiction as being consistent with this kind of "if and when" understanding. See infra text accompanying note 137 (Hamilton in ThE FEDERALIST No. 81); see also 3 Elliot's Debates, supra note 5, at 532-34 (remarks of James Madison) (defending federal jurisdiction in suits between a state and a foreign nation by asking: "Ought it to be put in the power of a member of the Union to drag the whole community into war?"); 4 id. at 159 (remarks of William Davie of North Carolina) ("It is impossible that there should be impartiality when a party affected is to be judge."); supra text accompanying note 97 (statement of Representative Stone in the first Congress); infra text accompanying notes 172-76. 
sion with most of article III's party-based jurisdictions, whose premise is that a state's courts are more likely to be partial to the state or its citizens than are the local federal courts.

Hamilton expressed his understanding of the party-based jurisdictions quite simply:

No man ought certainly to be a judge in his own cause, or in any case in respect to which he has the least interest or bias. This principle has no inconsiderable weight in designating the federal courts as the proper tribunals for the determination of controversies between different States and their citizens. ${ }^{137}$

That view seems to me hard to square with Amar's view that the state courts, but not the lower federal courts, are free to entertain such actions. ${ }^{138}$

In the end, Amar's geographical explanation of the original jurisdiction seems to me to lack persuasive power.

\section{Of Constitutjonal History and Structure}

\section{A. The Significance of the History}

What should one make of the historical record, however one reads it? Amar suggests, if only by implication, that the persuasiveness of his thesis depends heavily upon its grounding in the debates of 1787-89 and its consistency with the First Judiciary Act. He does admit that "the Act is perhaps not perfectly consistent, in every jot and

137 The Federalist No. 80 , subra note 30 , at 502-03.

138 The First Judiciary Act granted the Supreme Court non-exclusive original jurisdiction over some cases falling within both the ambassador and the state-as-party jurisdiction, without any express provision authorizing removal from a concurrent forum. The prospect that cases within the original jurisdiction might be finally tried in a concurrent forum, at least absent consent by all parties, see supra note 7 , poses difficulties for both Amar's view and for the traditional view of the original jurisdiction.

If a suit between a state and a non-citizen is litigated in state court, see, e.g., Plaquemines Tropical Fruit Co. v. Henderson, 170 U.S. 511 (1898), as $\S 13$ of the First Judiciary Act permitted, a problem is posed for the traditional explanation, but not for Amar, since such a case falls outside his mandatory tier. If such a suit is instead litigated in a federal district court, see, e.g., United States v. California, 328 F.2d 729 (9th Cir. 1964), a problem is presented for both Amar and traditionalists.

Similarly, when a suit falling within the "ambassador" jurisdiction is litigated either in state court (as the First Judiciary Act permitted in actions brought by diplomats, see Judiciary Act of 1789 , ch. $20, \S \S 9,13,1$ Stat. 73, 76-77, 80-81, or in a lower federal court (as the Act permitted in all cases against consuls and vice-consuls, see id.) a problem is presented for both Amar and for traditionalists. But cf. supra note 130 (noting possible argument that ambassador may waive the right to litigate in the Supreme Court). 
tittle, with the two-tier thesis"139 and adds that "few things in lifeand especially in law-are perfect." 140 But he repeatedly insists that the correspondence is really rather good, ${ }^{141}$ insisting that the inconsistencies "are not truly 'significant." "142 For me, Amar's thesis remains powerful despite its significant discontinuities within the Act and the pertinent constitutional and legislative debate.

My point is not simply the familiar one that questions the primacy, or even the coherence, of "originalist" approaches to constitutional interpretation. ${ }^{143}$ It is, rather, that the other most plausible theories about article III also have a hard time explaining some piece of the relevant history.

Consider, for example, the theory that the Constitution forbids Congress from impairing the Supreme Court's "essential role"-a role sometimes elaborated as discharging the "essential functions" of ensuring the supremacy and uniformity of federal law. ${ }^{144}$ This theory lacks historical and textual support, is difficult to square with the limited review provided by section $25,{ }^{145}$ and must confront the

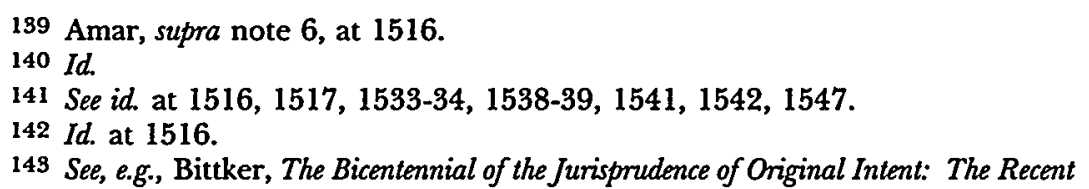
Past, 77 Calif. L. Rev. 235, 258-74 (1989); Brest, The Misconceived Quest for the Original Understanding, 60 B.U.L. Rev. 204, 205 (1980).

144 The argument's source was Henry Hart's comment, in his famous Dialogue, that Congress's power under the exceptions clause cannot be used to "destroy the essential role of the Supreme Court in the constitutional plan." See Hart, supra note 2, at 1365. Leonard Ratner has formulated this notion in the more developed form elaborated in the text. See Ratner, Congressional Power, supra note 65, at 200-01; Ratner, Majoritarian Constraints on Judicial Review: Congressional Control of Supreme Court Jurisdiction, 27 VILL. L. REv. 929, 933-36 (1982) [hereinafter Ratner, Majoritarian Consiraints].

145 See supra text accompanying notes 56-76. The one-way scope of $\S 25$ may be less embarrassing for the essential functions theorists than for Amar, since they can argue that unless the various state courts uniformly recognized a particular federal right, eventually the Supreme Court would have jurisdiction to review the issue and establish a uniform rule of decision. See Ratner, Majoritarian Constraints, supra note 144 , at 957. Amar's theory, by contrast, requires that an article III court review (or at least have jurisdiction to review) every case.

The uniformity prong of the essential functions thesis faces a second difficulty, one not faced by Amar. Under the First Judiciary Act, federal criminal cases were not reviewable as of right, but only through the limited writ of habeas corpus. See Judiciary Act of 1789, ch. 20, § 14, 1 Stat. 73, 81-82. The Judiciary Act of 1802, ch. 31, 2 Stat. 156, provided a second but also limited review mechanism-review of certified questions when the judges of the circuit court were divided. This structure necessarily limited the capacity promptly to achieve uniformity, but raises no problem for Amar, whose theory requires only that some federal court hear these cases. 
hard question whether the widely shared expectation that the Supreme Court would serve as the ultimate arbiter on questions of federal law is "tantamount to a constitutional limitation on congressional authority over appellate jurisdiction."146

The traditional position-that Congress has unlimited power over federal court jurisdiction (aside from the Supreme Court's original jurisdiction)_-also presents some difficulties. In affirming Congress's power to restrict Supreme Court appellate jurisdiction, this view must assign great weight to the exceptions clause, which was rather inconspicuous in the constitutional debate, at least in the Convention itself. ${ }^{147}$ Traditionalists must also deal with the arguments on which the other theories rely heavily: the important role that delegates to the Convention expected the Supreme Court to play (a point emphasized by essential functions theorists), and the range of textual, historical, and structural arguments emphasized by Amar (including particularly the framers' concerns about the trustworthiness of untenured state court judges).

A more specific question about the significance of history is this: How telling an objection is the lack of fit between Amar's interpretation and the First Judiciary Act? An important tradition treats the constitutional views of members of the first Congress as entitled to great respect. ${ }^{148}$ But one thing I have learned from delving into the surviving records of debates about the Act is how many of the participants were confused. (The same could be said about earlier debates over article III itself.) The confusion may be less attributable to the legislators' being ill-informed than to the content of article III, which does not seem to have been clearly thought through and is surely not a model of draftsmanship. Indeed, it is that lack of clarity which provides such fertile ground for the cultivation of rival accounts of article III.

Perhaps the most fundamental example of confusion involves the question whether article III obliges Congress to create lower federal courts or give them jurisdiction over any particular matters. The history of the Convention clearly shows that the answer is no; ${ }^{149}$ this is one point that would command agreement from Amar, from "essential functions" theorists like Hart and Ratner, and from traditionalists like Bator, Gunther, and Wechsler. Yet in the first Con-

146 Gunther, supra note 2, at 906. See generally id. at 901-10; Bator, supra note 2, at 1030, 1038-41; Redish, Power to Regulate, supra note 2, at 906-13.

147 On the origins of the clause, see infra text accompanying notes 193-96.

148 See supra note 55 and accompanying text.

149 See HART \& WEChSLER, supra note 2, at 10-11. 
gress (and, incidentally, in the ratification debates), it was not uncommon to hear just the opposite asserted. ${ }^{150}$

In addition to confusion, the congressional debates exhibited an uncertain mix of constitutional interpretation and sub-constitutional arguments about policy and politics. Though some members did distinguish between desirability and constitutionality, ${ }^{151}$ many speeches were in the far more ambiguous parlance of necessity or desirability.

Furthermore, today's congressional debates are uncertain evidence of contemporary constitutional understandings. ${ }^{152}$ Similar caution is equally appropriate in looking back to 1789 , when the new legislators may have been re-fighting old battles about the Constitution, ${ }^{153}$ unwilling to carry out any constitutional imperatives they divined. ${ }^{154}$

I do not mean to suggest that the First Judiciary Act, and the debates that gave rise to it, are not important elements of constitutional argument about article III's meaning. They are, and hence the question of how Amar's thesis squares with the Act is well worth careful consideration. But evidence of substantial tension between his thesis and the Act is not an interpretive trump that by itself shows Amar's thesis to be unfounded.

Amar at times offers a similar view of the importance of the First

150 See, e.g., ANNals of CoNG., supra note 14, at 827-28 (remarks of Rep. Gerry); supra text accompanying notes 111-20 (discussing views of Representative Smith and Senator Maclay in the first Congress). On the ratification debates, see 2 ELLIOT's Debates, supra note 5 , at 551 (Committee of Maryland Convention approved proposed amendment to the Constitution to "give a concurrent jurisdiction to the state courts, in order that Congress may not be compelled, as they will be under the present form, to establish inferior federal courts"); Hanson, Remarks on the Proposed Plan of a Federal Government, in Pamphlets on the Constitution of the United States 217, 236 (P. Ford. ed. 1888 \& republished 1968).

Other misconceptions included the view that the Supreme Court could review only federal court judgments, supra note 112 (remarks of Rep. Smith), and that article III's grant of federal judicial power was exclusive, see supra text accompanying notes 111-13 (remarks of Rep. Smith and Sen. Maclay); see also 3 Records, supra note 14, at 220 (reprinting Address of Luther Martin to the Maryland Legislature (Nov. 29, 1787)).

151 See, e.g., AnNals of ConG., supra note 14, at 800-01 (remarks of Rep. Smith); id. at 813 (remarks of Rep. Burke); id. at 809-10 (remarks of Rep. Stone).

152 For a discussion of doubts about Congress's capacity as constitutional interpreter, see Brest, Congress as Constitutional Decisionmaker and Its Power to Counter Judicial Doctrine, 21 GA. L. Rev. 57 (1986).

153 See Clinton, Early Implementation, supra note 6, at 1524-27; Warren, supra note 22 , at 62 .

154 See Amar, supra note 6, at 1540; $f$. $1 \mathrm{~W}$. Crosskey, supra note 18, at 610-11 (contending that Congress, in the First Judiciary Act, "contrived to slow down the process of change" contemplated by the Constitution's plan for the judiciary). 
Judiciary Act. ${ }^{155}$ Overall, however, his article conveys a somewhat different impression-that the degree of correspondence between the Act and his thesis is of critical importance. That impression arises, in part, from the article's focus on the Act. To this extent, the impression may be somewhat misleading, as the article grows out of a paper delivered at a conference devoted specifically to the First Judiciary Act. ${ }^{156}$ The impression is also based, however, on what Amar says: "Central to my argument about post-ratification American history was my claim that, beginning with the First Judiciary Act, congressional statutes had always reflected the basic principals underlying the two-tier thesis, with de minimis exceptions," 157 and "[v]irtually every major principle and premise underlying the twotier thesis was given voice-sometimes resoundingly, other times more faintly, yet nonetheless distinctly-in the legislative history of the First Judiciary Act."158

My impression also may result simply from our different interpretations of the Act and its history. Insofar as Amar's interpretations strike me as forced rather than forceful, I am impelled to think he must believe the degree of correspondence between the Act and his thesis is crucial. I would find Amar's thesis more convincing if he admitted that significant discontinuities exist between his thesis and the Act, but contended instead that when all the plausible arguments are considered, his position remains the most attractive one.

That kind of admission does not seem to me to render a decisive blow to his thesis. For though his arguments have a lot of historical trappings, history ultimately plays, if not a subordinate, then certainly not the dominant role in his interpretive methodology. Amar describes his Neo-Federalist interpretation of the Constitution as attempting "to offer a useable past-a set of Federalist doctrines in harmony with post-Federalist developments and the realities of twentieth-century life and law." 159 He thus offers us structural principles rooted as much in his understanding of present-day needs as in the views of the framing generation. One can say, without the least bit of criticism, that it is a form of lawyer's history. It is not the

155 See Amar, Neo-Federalist View, supra note 1, at 259.

156 Furthermore, Amar wished to respond to other commentators who have themselves interpreted the Act as supporting a rival understanding of article III. See Casto, supra note 55; Clinton, Early Implementation, supra note 6 . He also wished to respond to the questions about his thesis raised in Hart $\mathcal{E}$ Wechsler, see supra note 13 and accompanying text, some of which referred to the First Judiciary Act.

157 Amar, supra note 6, at 1515.

$158 \mathrm{Id}$. at $1565-66$.

159 Amar, Sovereignty, supra note 103, at $1427 \mathrm{n} .9$ (emphasis added). 
crude law office history of an advocate looking selectively for confirmation of his position, but it also is not the effort of an historian to reconstruct the constitutional and political understandings of the framing generation for their own sake, rather than in conscious service of a normative argument about constitutional interpretation. ${ }^{160}$ It is, rather, the use of history and structural argument in a kind of reflexive process, employing each to illuminate and reinforce the other. ${ }^{161}$

Given that methodology, it is not surprising that Amar, while stressing the importance of text, the views of the framers, and the First Judiciary Act, places great emphasis on the "underlying structural vision" on which his thesis rests. ${ }^{162} \mathrm{He}$ is not alone in stressing structural interpretation; each of the other two theories of article III that I have mentioned-the "essential functions" position and the traditionalist position-includes an important set of structural arguments. ${ }^{163}$ Given the centrality of Amar's structural vision of article III, I wish to explore some of that vision's key elements.

160 Some students of interpretation would claim that Amar is merely conscious that he is doing what the rest of us do unconsciously-reading the past through our own experiences. See, e.g., R. Bernstein, Beyond Objectivism and Relativism: Science, Hermeneutics, and Praxis (1983); see also P. Novick, That Noble Dream: The "Objectivity Question" and the American Historical Profession (1988) (providing a history of the idea of historical objectivity among American professional historians). My own view is that while there exists no objective Archimedean point from which to evaluate historical events, historical observers have a significant capacity to control the extent to which their historical understandings are shaped by present day experiences and concerns, and good historians try very hard to do so. Indeed, if legal advocates (who selectively adduce historical evidence to support their clients' positions) were indistinguishable from historians (who, the argument would go, selectively adduce historical evidence to support their ideology or preconceptions), the phrase "law office history" would not resonate with us as it does.

161 For a sensitive discussion of these and related issues, see Fallon, $A$ Constructivist Coherence Theory of Constitutional Interpretation, 100 HARV. L. REv. 1189 (1987).

162 Amar, supra note 6, at 1566; see also id. at 1508.

163 Each also rests on textual arguments: Amar's on the words "all" and "shall"; the essential functions thesis on the phrase "such exceptions . . . as Congress shall make," with the word "exceptions" read as more limited than a power to withhold jurisdiction altogether, see Ratner, Congressional Power, supra note 65, at 16871; and the traditionalist position also on the exceptions clause, which is read instead as a grant of unlimited power to Congress, see, e.g., Redish, Power to Regulate, supra note 2 , at 906-07. 


\section{B. Structural Argument and Article III}

\section{The Range of: Amar's Structural Arguments}

A striking feature of A.mar's thesis is the variety of structural arguments that he musters. Their sheer number seems to add great power to his account. On inspection, however, there is a kind of mismatch between his thesis and many of the arguments he musters.

Amar refers repeatedly to the "coextensiveness principle": that federal courts must speak authoritatively in cases arising under federal law, whether in law, equity, or admiralty. ${ }^{164}$ But that principle does not fit the two tiers he describes. Though Amar asserts that "federal norms" are "virtually always" implicated in admiralty, ${ }^{165}$ admiralty cases were not viewed as cases under federal law until the twentieth century. ${ }^{166}$ Rather they were seen as constituting "a separate corpus of law claiming the respect of all maritime nations."167 Furthermore, cases affecting; ambassadors were probably more likely to arise under nonfederal than federal law. ${ }^{168}$ Thus, the "coexten-

164 Amar, supra note 6 , at $15 ! 1-12,1539,1557,1563-65$.

165 Id. at 1513.

166 See, e.g., American Ins. Co. v. Canter, 26 U.S. (1 Pet.) 511, 545 (1828) ("A case in admiralty does not, in fact, arise under the constitution or laws of the United States."). See generally supra note 84; supra text accompanying notes 82-89.

167 Hart, The Relations Between State and Federal Law, 54 Colum. L. Rev. 489, 531 (1954). The "mandatory" admiralty jurisdiction thus might be viewed as very similar to the "non-mandatory" jurisdiction over controversies between two states. Both implicate uniquely federal interests, may require adjudicating competing rights of different sovereigns, and are governed by a body of judge-made law that draws in part on the law of nations, see New Jersey v. Delaware, 291 U.S. 361, 378-83 (1934); see also Connecticut v. Massachusetts, 282 U.S. 660, 670 (1931); Kansas v. Colorado, 206 U.S. 46, 98 (1907), and that is now viewed as federal common law, see HarT \& WECHSLER, supra note 2 , at $318-22,884$; see also supra note 84 and accompanying text.

Insofar as admiralty cases involved federal statutes, article III's "arising under" jurisdiction, limited as it is to case.s in "law and equity," might not alone satisfy the coextensiveness principle, as an admiralty case may have been understood as a form of action different from a suit in law or equity, see supra text accompanying notes 8289. But admiralty cases involving fiederal legislation were presumably a small portion of admiralty actions generally, and Amar's coextensiveness principle could have been satisfied by the far more modest specification of an "arising under" jurisdiction in cases in "law, equity, or admiralty."

168 Amar recognizes this difficulty, but suggests that it is somehow cured by the fact that the cases arise under the Supreme Court's original jurisdiction, which Congress has no authority to limit. See Amar, supra note 6, at 1513. The suggestion is correct, but not really responsive; it does not address the mis-match between the coextensiveness principle and his inclusion of the ambassador jurisdiction within the mandatory tier. Indeed, when he does discuss the Court's original jurisdiction, he relies on the premise that the ambassador component is mandatory because it falls within the first tier. See Amar, supra note 6, at 1524-25. Hence, his argument ultimately fails to meet the objection. 
siveness" principle cannot explain the two tiers as defined by Amar. ${ }^{169}$

A second structural point on which Amar's thesis relies is the "principle of inadequate political safeguards"-that mandatory federal court jurisdiction is necessary to protect constitutional rights. ${ }^{170}$ But that argument plainly calls for a far narrower mandatory tier, excluding not only ambassador and admiralty cases, but suits arising under federal statutes and treaties. ${ }^{171}$

A third component of Amar's argument is the "principle of structural superiority"- that article III judges, federally appointed and constitutionally protected as to tenure and salary, are superior to state court judges, who are vulnerable to political and parochial pressures. ${ }^{172}$ Here, too, the premise (even if accepted) does not clearly fit the two-tier thesis. After all, the six party-based jurisdictions were created precisely because the cases within them presented special risks of state court partiality. Why, then, is "structural superiority" less important in the non-mandatory than the mandatory tier? Or to put that question more concretely, is there less risk of bias when a state court adjudicates a suit brought by the forum state against a non-citizen, or an action involving rival land grants from the forum state and its neighbor, than when the state court adjudicates a federal question action between a patent-holder and an alleged infringer?

Amar's response is that the party-based jurisdictions were made non-mandatory because of the risk of local parochialism was expected to erode over time ${ }^{173}$ - a familiar, though hardly uncontroversial, element of modern debate about diversity jurisdiction. ${ }^{174}$ By contrast, the risk of state court political dependence when deciding issues within the mandatory tier was ineradicable. Stated this way, the principle of structural superiority partially fits his thesis-to the same extent as the coextensiveness principle.

But two points about his argument are worth noting. First, I

169 Amar acknowledges that many of the comments he cites as evidence supporting the coextensiveness principle pertain only to federal question jurisdiction. See Amar, supra note 6, at 1565.

170 See id. at 1512-13, 1564; Amar, Neo-Federalist View, supra note 1, at 220-24.

171 See Redish, Constitutional Limitations, supra note 5, at 152; see also supra text accompanying note 5 (criticizing a related argument by Lawrence Sager).

172 See Amar, supra note 6, at 1509-10, 1559-63.

173 Amar, Neo-Federalist View, supra note 1, at 246.

174 Compare H. Friendly, Federal. Jurisdiction: A General View 147-48 (1972) with Shapiro, Federal Diversity Jurisdiction: A Survey and a Proposal, 91 Harv. L. REv. 317, 329-32 (1977). 
think it is not unfair to describe his definition of the principle as coming rather close to incorporating the very two-tier thesis in whose support it is offered. Second, the evidence that the framers distinguished between these two potential vices of state courts, and viewed parochialism as more transitory, is uncertain at best. ${ }^{175}$ To me, it seems improbable, for example, that the framers would have expected that over time, a Massachusetts court could be trusted fairly to uphold a land grant from Connecticut in preference to one from Massachusetts, but not to uphold a federal patent. It seems similarly doubtful that the framers would have expected that after some years had passed, if Massachusetts sued Connecticut in Massachusetts state court, the problem of "horne court advantage" would have disappeared. Thus it is far from clear that the structural superiority principle offers much support for the two-tier thesis. ${ }^{176}$

175 Amar does provide support for the view that in the ratification debates, diversity jurisdiction was viewed by some important federalists as non-essential, see, e.g., Amar, Neo-Federalist View, supra note 1, at $245 \mathrm{n.130}$, though their statements may have been strategically motivared. In any event, the more precise claim noted in the text-that the framers anticipated the decline of parochialism favoring the forum state, or its citizens against outsiders, but not of parochialism favoring state law over federal law-seems to lack support. Cf. ThE FEDERALIST No. 81, supra note 30 , at 510 (in discussing federal question jurisdiction, noting that "the most discerning cannot foresee how far the prevalency of a local spirit may be found to disqualify the ${ }^{\prime}$ local tribunals for the jurisdiction of national causes . . . ."); supra text accompanying notes 39-41.

In the present piece, Amar cited excerpts from the notes for the speech in the first Congress by William Paterson. See Amar, supra note 6, at 1555. A fuller citation of those notes is as follows:

Become one People. We must have Tribunals of our own pervading every State, operating upon every Object of a national kind. Hence Uniformity of Decision-Hence we shall approximate to each other gradually-Hence we shall be assimilated in Manner, in Laws, in Customs-Local Prejudices will be removed-State Passions \& Views will be done away-the Mind expands-it will embrace the Union; we shall think and feel, \& act as one People-

Casto, supra note 55, at 1130-31. Here, too, the discussion of prejudice, prefaced as it is by discussion of uniformity of decision, appears to relate at least as much to federal question jurisdiction (or more generally, to the existence of uniform national regulation) as to party-based jurisdictions.

176 As Amar recognizes, that principle also fits uneasily with the limitation of the Supreme Court's jurisdiction to review state court judgments via certiorari. The development of certiorari does not undercut the force of Amar's historical argument, for at its inception the Supreme Court had the capacity to review all state court decisions, and there is no reason to believe that the framers anticipated the dramatic increases in its workload. See Amar, Neo-Federalist View, supra note 1, at 267. But insofar as Amar presents the structural superiority principle as a guide to constitutional interpretation today, there is a real problem squaring his thesis with a 


\section{The Parity of Supreme and Inferior Federal Courts}

Amar relies heavily on still another structural argument, one that he deems the "most important" of all. ${ }^{177}$ For him, a crucial structural feature of article III's design is that Supreme Court and lower federal court judges are in constitutional parity with each other. Thus, article III is indifferent whether mandatory tier cases are heard by the Supreme Court on appeal or by the lower federal courts in the first instance. ${ }^{178}$ His claim of parity within the federal judiciary permits him to resist the contention that the Constitution requires creation of a federal court system that can ensure uniform interpretation of federal law. ${ }^{179}$ For that argument, if accepted, points toward limits on Congress's power to restrict the Supreme Court's jurisdiction in particular, rather than that of the federal courts as a whole.

I find Amar's suggestion of parity between the Supreme Court and lower federal courts unpersuasive. Article III, after all, itself prescribes a single Supreme Court not subject to further review, while leaving creation of the lower federal courts to congressional choice. ${ }^{180}$ The specification of the Supreme Court's original juris-

system in which, as a practical matter, nearly all state court suits that "arise under" federal law for the purposes of article III are unreviewable.

Though Amar thinks that this development is in tension with the "spirit" of article III, he does not view the denial to a state court litigant of a right to Supreme Court review as an actual constitutional violation, because Congress has not limited the Supreme Court's power to review any particular state court judgment. See id. at 267-69. But if, as Amar asserts, the framers thought that "dramatic differences in selection, tenure, and removal procedures between state and federal benches translate into predictable long-run differences in decisional outcomes," Amar, supra note 6 , at 1509 , and that the likely state court outcomes were constitutionally intolerable unless some article III court had the final word, see id. at 1510 , then it is hard to see why certiorari is not unconstitutional in fact as well as in spirit. See supra note 13. As he points out, providing federal review in every case is not in fact impracticable: Congress could restrict the scope of federal jurisdiction in the "nonmandatory" categories, authorize the lower federal courts to review state court decisions, and prescribe that the Supreme Court (like the courts of appeals) should ordinarily hear cases in panels of three, reserving en banc review for cases of special importance.

177 Amar, Neo-Federalist View, supra note 1, at 221; see also Amar, supra note 6, at 1510.

178 See Amar, Neo-Federalist View, supra note 1, at 221-22, 254-58; Amar, supra note 6 , at 1510 .

179 See Clinton, Early Implementation, supra note 6, at 1518 n.5.

180 Amar notes these points and states that he does not "deny the Supreme Court's unique constitutional position," Amar, Original Jurisdiction, supra note 1 , at 466 n.107, but at the same time he does not ascribe much significance to it. He argues, for example, that the First Judiciary Act's provision that Supreme Court 
diction also suggests (particularly if I am right in discounting Amar's geographical explanation) that there is something unique about that tribunal. Moreover, at the Convention, in the ratification debates, and in the first Congress, there surely was a widespread expectation that the Supreme Court would exercise appellate jurisdiction, often coupled with the observation that only such review could ensure uniformity. ${ }^{181}$ That expectation may explain why Madison stated that "[t]he most material part [of article III's organization of the judiciary] is the discrimination of superior and inferior jurisdiction." 182

It may well be, as the traditionalists argue, that insisting that the

Justices sit with district judges or. the circuit courts supports his claim of parity. See Amar, supra note 6 , at 1537. However, whatever questions circuit riding may have raised under the appointments cliause, see Currie, The Constitution in the Supreme Court: The Powers of the Federal Courts, 1801-1835, 49 U. CHr. L. Rev. 646, 663-64 (1982), the circuit and Supreme Courts were rather clearly distinguishable on the bases noted in the text.

181 See, e.g., ANNAls of Conc., supra note 14, at 829 (remarks of Rep. Smith); id. at 848 (remarks of Rep. Sherman); 3 Elliot's Debates, supra note 5, at 518-19 (remarks of Edmund Pendleton); $4 \mathrm{id}$. at 147 (remarks of James Iredell); Essays on The Constitution, supra note 91, at 155, 159 (reprinting Letter to Landholders and Farmers from a Landholder (V), Conn. Courant, Dec. 3, 1787 (attributed to Oliver Ellsworth)); The FEDERALIsT Nos. 22, 80, 82, supra note 30, at 197, 500, 516-17; HART \& WECHSLER, supra note 2, at 11; 1 RECORDS, supra note 14, at 124 (remarks of John Rutledge); Casto, supra note 55, at 1129-30, 1135,1138 (reprinting notes of Senator Paterson); see also Cohens v. Virginia, 19 U.S. (6 Wheat.) 264, 416-18 (1821); Martin v. Hunter's Lessee, 14 U.S. (1 Wheat) 304, 347-48 (1816).

There is a different respect in which the Supreme Court and lower federal courts are not interchangeable, a point noted by both Madison and Hamilton. Madison concluded

that unless inferior tribunals were dispersed throughout the Republic with final jurisdiction in many cases, appeals would be multiplied to a most oppressive degree; that besides, an appeal would not in many cases be a remedy. What was to be done after improper Verdicts in State tribunals obtained under the biassed directions of a dependent Judge, or the local prejudices of an undirected jury?

1 ReCorDs, supra note 14, at 124. Hamilton echoed this point:

The right of appeal is by no means equal to the right of applying, in the first instance, to a Tribunal agreeable to the suitor. The desideratum is to have impartial justice, at a moderate expence, administered 'promptly and without delay;' not to be obliged to seek it through the long and tedious and expensive process of an appeal. It is true, that in causes of sufficient magnitude, an appeal ought to be open; which includes the possibility of going through that process: but when the Courts of original jurisdiction are so constituted as not only to deserve but to inspire confidence, appeals, from the inevitable inconvenience attached to them, are exceptions to the general rule of redress ....

4 The Founder's Constrtution 166-67 (P. Kurland \& M. Lerner eds. 1987) (reprinting Hamilton, The Examination, No. 6 (Jan. 2, 1802)).

1823 Elliot's Debates, supra note 5, at 534. 
Supreme Court have power to create uniformity (or to enforce supremacy) confuses familiar and desirable arrangements with constitutionally required ones. ${ }^{183}$ Or it may be, as Leonard Ratner has argued, that creation of both uniformity and supremacy should be viewed as constitutionally required. ${ }^{184}$ Is there, however, a coherent basis for concluding, as Amar does, that article III does protect the supremacy of federal law (vis-a-vis the states and the federal political branches), but does not require uniformity?

One possible answer, given by Amar in his reply, is that the First Judiciary Act, by limiting the Supreme Court jurisdiction to review lower federal courts decisions, clearly contemplated non-uniformity. ${ }^{185}$ But if the First Judiciary Act is decisive evidence that uniformity is not required, then it presumably is equally decisive evidence (unless Amar's discussion of section 25 is found persuasive) that even the federal question jurisdiction is not mandatory. Is there some other basis, then, for reading article III as mandatory (in first tier cases), but wholly indifferent to the uniformity of federal law?

\section{C. "The Holistic Principle"}

For Amar, a possible answer is provided by what he calls "the holistic principle," for a key element of his interpretation is that article III should be viewed as a whole. ${ }^{186}$ This suggestion is appealing, particularly when contrasted with his characterization of the alternative as "selective literalism's divide-and-conquer (il)logic"187 For me, a good part of his argument's ingenuity and attractiveness comes from his effort to link three different aspects of article III: the tenure and salary protection, the exceptions clause, and the discretion of Congress in creating lower federal courts. If his theory in fact provides a coherent account of these various elements of article III, is it not the most satisfying structural interpretation of that provision?

To answer that question, we need briefly to review the framing of the judiciary article at the Convention. There was little dissent from the suggestion that federal judges should enjoy tenure and sal-

183 See, e.g., Gunther, supra note 2, at 908.

184 See Ratner, Congressional Power, supra note 65.

185 See Amar, Reply, supra note 9, at 1670.

186 See Amar, supra note 6, at 1506-07.

187 See id. at 1506-07. Robert Clinton is similarly pejorative about arguments that, in his view, take separate clauses of article III "out of context" and "in isolation." Clinton, $A$ Guided Quest, supra note 4, at 797 n.177. 
ary protection, ${ }^{188}$ or that the Constitution should call for a Supreme Court. ${ }^{189}$ Far greater disagreement surfaced about the desirability of creating lower federal courts. The Committee of the Whole, having initially approved the mandatory establishment of inferior federal courts, subsequently voted to eliminate them entirely. Later the same day, the Committee approved a compromise, moved by Madison and Wilson, to permit but not require Congress to create inferior federal courts. ${ }^{190}$ Opposition to that compromise resurfaced when the Committee's report came before the Convention, but in the end the "Madisonian Compromise" was unanimously approved. ${ }^{191}$

Amar's theory is entirely consistent with congressional prerogative to create lower federall courts. It is consistent, too, with Congress's having broad power under the exceptions clause to limit Supreme Court jurisdiction. But echoing Robert Clinton, he characterizes the exceptions clause as "empowering Congress to shift the last word on any case in the Supreme Court's appellate jurisdiction to lower federal courts." 192 Under that interpretation, an article III judge, loyal to national interests and protected from political interference, would resolve all nnandatory tier cases.

As elegant and alluring as this argument is, Amar's account could be seen as a somewhat unlikely interpretation of the Convention's proceedings. The exceptions clause was drafted in the Committee of Detail, ${ }^{193}$ only after the Convention had forged a compromise on lower federal courts. As Lawrence Sager notes, that clause "was adopted by the Convention on August 27 without a rip-

188 The principal dispute involving this provision was whether increases as well as decreases in salary should be prohibited. See HART \& WECHSLER, supra note 2, at 6.

189 There was clearly an expectation that state court decisions would be reviewable by the Supreme Court. See sources cited supra note 181 .

190 The history and supporting citations are set forth in HART \& WECHSLER, supra note 2, at 10-11.

191 See 2 RECords, supra note 14, at 45-46.

192 Amar, supra note 6, at 15il0; see also Clinton, $A$ Guided Quest, supra note 4, at 753-54.

193 See 2 RecoRds, supra note 14, at 38-39, 45-46, 186-87. The Committee appears to have taken the language from a draft in James Wilson's handwriting. See id. at 173.

A plan of Hamilton's, apparently never presented as such to the Convention, provided for appellate jurisdiction in certain cases, "subject to such exceptions as are herein contained and to such regulations as the Legislature shall provide." 3 id. at 626. The plan may have been the basis for his speech of June 18 , but the surviving records of that speech include no reference to the "exceptions" language. See 1 id. at 283-304. 
ple of recorded debate, concern, or explication."194 On Amar's account, the Committee of Detail added, the Convention approved, and the states ratified, a power to limit Supreme Court jurisdiction that, insofar as actually exercised in mandatory tier cases, would effectively undo the Madisonian compromise and require vesting of lower federal court jurisdiction. In one respect, the exceptions clause assumes less significance in Amar's view than in the traditional view, because Congress cannot simply eliminate Supreme Court jurisdiction, but must transfer it to the lower federal courts. ${ }^{195}$ But in another sense, the clause assumes more significance under Amar's reading, for the creation of exceptions would result in the imposition on Congress of the very obligation to create lower federal courts that the Convention had so clearly rejected. ${ }^{196}$

Though one hesitates to argue, given the state of the historical records, that surely someone would have commented on such a central change, the question cannot be entirely dismissed. ${ }^{197}$ Put differently, it is far from clear that the delegates in Philadelphia and in the various state ratifying conventions viewed tenure and salary protection, congressional prerogative in creating lower federal courts, and the exceptions clause as in fact interconnected.

If Amar's theory is, from one angle too holistic, it may be not holistic enough from another. Amar's argument focuses primarily on various clauses of article III. Some traditional theorists, by contrast, would emphasize the relationship of congressional control over jurisdiction to the institution of judicial review itself-particularly to the scope and indeterminacy of the Constitution, and the correspondingly great power that courts necessarily exercise when called upon to enforce it. Charles Black, the dean of structural constitutional interpretation, has argued that congressional power to control federal court jurisdiction "is the rock on which rests the legitimacy of the judicial work in a democracy."198

194 Sager, supra note 3 , at 51 . The clause was referred to frequently in the ratification debates, but in the specific context of limiting the Supreme Court's power to review issues of fact resolved by juries. See, e.g., Clinton, A Guided Quest, supra note 4 , at 803-10.

195 See Amar, Reply, supra note 9, at 1658.

196 Cf. id. at 1654 (criticizing Martin Redish as reading the exceptions clause as "an implied repeal of unambiguous prior commands").

197 Cf. Sager, supra note 3, at 51 ("In light of this quiescence, it is hard to imagine that the framers were consciously adopting a provision that could completely unravel one of the most basic aspects of the constitutional scheme to which they had committed themselves [the Supreme Court's superintendence of state compliance with the Constitution].").

198 Black, The Presidency and Congress, 32 Wash. \& LeE L. Rev. 841, 846 (1975); see 
Admittedly, one could acknowledge these features of judicial review without necessarily agreeing with Black's position. One's conclusion probably depends, I think, on how one approaches the inescapable tension between judicial independence and political accountability, ${ }^{199}$ or, put clifferently, whether one views greater judicial freedom from congressional control as making judges autonomously political rather than apolitical. ${ }^{200}$ An appeal to holism cannot resolve that question.

I have a final, and more general, question about Amar's appeal to "the holistic principle." All first-year law students learn the critical importance in legal argument of the generality with which a proposition is framed. Last year, for example, Justice Scalia suggested that, in relying upon historical tradition as a guide to constitutional argument, "[w]e refer to the most specific level at which a relevant tradition protecting, or denying protection to, the asserted right can be identified."201 Predictably, a number of his colleagues disagreed. ${ }^{202}$ At the other end of the spectrum, one might take a holistic approach to the Bill of Rights, and seek a general theory of

also M. Perry, The Constrtutiolv, The Courts, and Human Rights 125-35 (1982) (Congress may restrict jurisdiction to engage in "noninterpretive" judicial review); Wechsler, supra note 33, at 10.48. More tentatively, Hart $E$ Wechsler raises the question whether it is "perhaps politically healthy that the limits of congressional power over Supreme Court appellate jurisdiction have never bean completely clarified." HART \& WECHSLER, supra note 2, at 381.

199 See, e.g., Seidman, Ambivalence and Accountability, 61 S. CAL. L. REv. 1571 (1988). This tension was recognized in the founding era. See, e.g., 2 H. STORING, supra note 19, at 439-42 (reprinting Essay of Brutus (Mar. 29, 1788)).

The relationship between those views and conclusions about congressional control over jurisdiction is not, however, simple or predictable. For example, the view that article III does not limit Congress's power to restrict federal court jurisdiction is shared (i) in part by Michael Perry, an advocate of broad noninterpretive review, see M. PERRY, supra note 198, at 128-45; (ii) by Charles Black, a "judicial activist proudly self-confessed," see C. BLACK, STructure and Relationship IN ConstTTUTIONAL LAw 72 (1969); supra note 198 and accompanying text; and (iii) by scholars far more skeptical about judicial activism, see, e.g., Bator, supra note 2; Gunther, supra note 2; Wechsler, supra note 2.

200 Compare R. Posner, The Federal Courts 16 (1985) (expressing the first view) with Amar, Neo-Federalist Vieu', supra note 1, at 230 (expressing the second view).

201 Michael H. v. Gerald D., 109 S. Ct. 2333, 2344 n.6 (1989) (plurality opinion) (finding that putative biological father of child whose mother was married to another man when child was born has no liberty interest in relationship with the child).

202 See id. at 2346-47 (O'Connor, J., joined by Kennedy, J., concurring in part); id. at 2347 (Stevens, J., concurring in the judgment); id. at 2349-51 (Brennan, J., joined by Marshall and Blackmun. JJ., dissenting). 
constitutional protection of individual liberty, perhaps akin to Justice Brandeis's "right to be let alone."203

My point is not that either Justice Scalia or Justice Brandeis was right, or that argument about the appropriate level of generality is necessarily hopeless or arbitrary. It is, rather, that holism is not an obviously desirable interpretive canon, precisely because it pushes toward a greater level of generality in constitutional interpretation. ${ }^{204}$

\section{Federal Jurisdiction and the Dual Concepts of Parity}

Though I have expressed a number of doubts about Amar's thesis, they should not conceal my keen admiration for its originality, ingenuity and power. In comparing it to rival accounts, I have at times felt a bit like the rabbi who, the story goes, was asked to resolve a dispute. After hearing one side's account of the matter, the rabbi declared, "You're right." After the second disputant gave his account, the rabbi told him, "You're right." When a bystander objected, "Rabbi, they can't both be right," the rabbi responded, "You're right."

Amar insists, however, that it is important to take a stand, and one who rejects his theory must endorse a competing one and argue for its superiority. ${ }^{205}$ His reply goes further, contending that $I$ have failed to (1) "set out the (hi)story as [he] set it out, and show why [he is] wrong,"206 (2) present an "integrated counternarrative of the 'traditional' position," 207 and (3) take on Robert Clinton's broader mandatory thesis. ${ }^{208}$ I plead guilty to the gist of the charge. I do not present the same historical narrative as he does, one viewed through the lens of his thesis and its supporting "principles," for I do not

203 Olmstead v. United States, 277 U.S. 438, 478 (1928) (Brandeis, J., dissenting).

204 See generally Blasi, Creativity and Legitimacy in Constitutional Law (Book Review), 80 YALE L.J. 176, 183 (1970) (discussing the indeterminacy of structural approaches to constitutional interpretation). As Charles Black's interpretation of article III demonstrates, a more holistic approach does not necessarily result in expanded constitutional limits. But in individual rights cases, where t:se problem is a familiar one, a holistic approach is likely to lead to more expansive interpretation of constitutional protections. See Brest, The Fundamental Rights Controversy: The Essential Contradictions of Normative Constilutional Scholarship, 90 YALE L.J. 1063, 1084-85 (1981).

205 See Amar, Reply, supra note 9, at 1662.

206 Id.

207 Id. at 1671.

208 See id. at 1657. For brief discussion of Clinton's views, see supra text accompanying notes $4-8$. 
interpret the text and history just as he does. Nor have I been able, in this discussion of Amar's account, to cover as much terrain as he and Clinton have covered in five articles and well over four hundred pages. ${ }^{209}$ But I hope that from what I have written, the reasons are clear why I find Amar's thesis, though very powerful, not quite persuasive. (Some of my reasons have been presented by others, though these articles, written before Amar's, do not discuss his thesis.) ${ }^{210}$ Amar's reply tries to demonstrate the comparative superiority of his view. In doing so, he emphasizes some points but not others. The reader has plenty of raw material to consider in reaching an independent judgment.

Here, I wish to address a different question: why does Amar insist that it is important to resolve which theory is most satisfactory-and more generally, what is at stake in the debate over the scope of congressional power to regulate federal court jurisdiction?

The volume of commentary about congressional control of federal court jurisdiction is in some respects curious. Recent congressional efforts to restrict federal court jurisdiction have not even passed both Houses, much less avoided presidential veto. Moreover, apart from the gaps already noted, it is not clear that Congress has ever passed a statute that Amar would find unconstitutional. ${ }^{211} \mathrm{~A}$ variety of practical, political, and structural forces suggest that this

209 See Amar, Original Jurisdiction, supra note 1; Amar, A Neo-Federalist View, supra note 1; Amar, supra note 6; Clinton, $A$ Guided Quest, supra note 4; Clinton, Early Implementation, supra note 6.

210 See, e.g., Bator, supra note 2, at 1041; Gunther, supra note 2, at 908-10; Wechsler, supra note 2, at 1001.

211 The Norris LaGuardia Act, 47 Stat. 70 (1932) (codified at 29 U.S.C. $\$$ 10115 (1982)), forbids the federal courts to issue injunctions in labor disputes (except in narrowly specified circumstances) or to enforce "yellow dog" contracts. The Act would violate Amar's understanding of article III only.insofar as (i) a party had a constitutional right to an injunctive remedy in a labor dispute, or to enforcement of a "yellow-dog" contract, and (ii) the Act bars the Supreme Court from reviewing a state court decision denying injunctive relief or enforcement of a contract (as distinguished from the Court's issuing the relief itself). On the second point, the Act forbids any court of the United Sitates, defined to include the Supreme Court, "to issue" an injunction, and provides that no yellow dog contract shall be "enforceable in any court of the United States." Id. \$§ 103-07, $113(\mathrm{~d})$.

The Emergency Price Control Act of 1942, 56 Stat. 23, precluded any court, state or federal, from issuing interlocutory relief, while the Portal-to-Portal Act of 1947, 29 U.S.C. \$\$ 251-62 (1982), barred any court from hearing certain claims. Only if these last two Acts barred constitutionally-required relief would they be unconstitutionalfor Amar because they foreclosed article III review, for others because "a court must always be available to pass on clains of constitutional right to judicial process, and to provide such process if the claim is sustained." Hart, supra note 2, at 1372. 
lack of success is anything but coincidental. ${ }^{212}$ Authoritative rejection of Amar's thesis would not, I suspect, increase the likelihood of “jurisdiction stripping."

Nor would acceptance of his thesis have important concrete consequences. Current jurisdictional arrangements fail to vest federal judicial power in his mandatory tier only in some aspects of the ambassador and arguably the admiralty jurisdictions, ${ }^{213}$ and I do not read Amar's writings as manifestos for slight expansions of federal court jurisdiction in these areas.

Still, Amar asserts that it matters a good deal whether his thesis is accepted. He quite properly notes that the question of congressional power to control jurisdiction goes to the heart of the role of the federal courts, and adds that one never knows when a genuine threat of jurisdiction-stripping might emerge. But more than once, he stresses an additional point: for him, the debate over congressional power to control federal court jurisdiction relates to a general question about the "parity" between state and federal courts:

First, the Court has often indulged in rhetoric propagating the myth of parity, even as the Court has at other times spoken more accurately on the subject. Second, the Court has proliferated a confusing assortment of various abstention doctrines, and dramatically expanded the scope of many of the individual categories of abstention. Not only do many of these decisions smack of ad hocery, and disregard the spirit as well as the letter of congressional statutes allocating various cases to federal courts, these decisions also turn the principles of article III and the First Judiciary Act on their heads....214

I agree with some (though only some) points in this indictment:

212 See, e.g., Tushnet \& Jaff, Why the Debate Over Congress' Power to Restrict the Jurisdiction of the Federal Courts Is Unending, 72 GEo. L.J. 1311, 1325-27 (1984); Wechsler, supra note 2, at 1006-07.

213 See supra text accompanying notes 55-103. But cf. supra note 59 (noting arguable gaps in arising under jurisdiction).

It is also possible that endorsement of his view might call for reconsideration of the constitutionality of the discretionary certiorari jurisdiction in reviewing state court judgments. See supra note 176.

214 Amar, supra note 6, at 1535 (footnotes omitted); see also id. at 1500-01; Clinton, $A$ Guided Quest, supra note 4, at $814 \mathrm{n} .233$ (drawing on his understanding of article III in criticizing the Supreme Court's administration of the federal habeas corpus jurisdiction in Stone v. Powell, 428 U.S. 465, 493-94 \& n.35 (1976), and particularly the Court's assumption that state courts are as competent as federal courts in deciding fourth amendment issues). 
the Court's rhetoric is surely inconsistent, ${ }^{215}$ its abstention cases confusing and often unpersuasive. ${ }^{216}$ For me, though, the important

215 See Fallon, The Ideologies of Federal Courts, 74 VA. L. REv. 1141, 1142-43 (1988).

216 Whatever the merits of particular decisions, I do not agree that judge-made abstention doctrines disregard the spirit and letter of congressional grants of jurisdiction. See generally Bator, supra note 66 , at 622 \& $n .49$ (jurisdictional grants must be read against "the background of a large body of standing law in matters of substance, remedy and jurisdiction"); Shapiro, Jurisdiction and Discretion, 60 N.Y.U. L. Rev. 543, 543 (1985). But see Redish, Abstention, Separation of Powers, and the Limits of the Judicial Function, 94 YALE L.J. 71, 72 (1984) (claiming that abstention in some cases prohibits "the federal courts from enforcing federal civil rights laws").

In this respect, Amar also takes issue with Rooker v. Fidelity Trust Co., 263 U.S. 413, 415-16 (1923), which held that the Supreme Court's appellate jurisdiction over state court judgments impliedly precludes exercise of the district courts' federal question jurisdiction to declare a state court decision void. Amar justly criticizes the description of Rooker, in the preface to Hart $\xi$ Wechsler, as a "classic." See Amar, supra note 6, at 1535-36 (quoting HART \& WECHSLER, supra note 2, at xxi). Even since its recent emergence from obscurity, see, e.g., District of Columbia Court of Appeals v. Feldman, 460 U.S. 462, 476 (19.83), Rooker might not even satisfy Mark Twain's definition of a classic as a work "which people praise and don't read," M. TwaIN, Following the EQUATOR: A Journey ARound THE World 241 (1897), for Rooker may just be wrong. The ordinary doctrine limiting collateral attack on a final adjudication is res judicata, and it is doubtful that "statutes providing for appellate review should be read as generating an independent set of rules to the same end." HART \& WeChSLER, supra note 2, at 1632-34.

Amar objects for a different reason to Rooker, which he reads as suggesting that federal district courts may exercise original but not appellate jurisdiction over state courts. But Rooker holds only that the congressional grant of federal question jurisdiction did not permit district courts to entertain collateral attacks on state court judgments, not that Congress could not have granted such power. See Rooker, 263 U.S. at 415-16.

Some of the broader language in Rooker can (though need not) be read as suggesting that all grants of district court jurisdiction, not merely the federal question jurisdiction, preclude the district courts from hearing appeals from the state courts. See id. at 416. Amar complains that such a suggestion is in tension with other statutes that do provide for "appellate jurisdiction," "both de jure (civil rights and federal officer removal) and de facto (habeas corpus, certification, and the England reservation to Pullman abstention)." Amar, supra note 6, at 1536 (footnotes omitted). But neither certification nor Pullman abstention involves an appeal from the state courts; suit is filed in federal court first, and the federal court chooses to defer to (and ordinarily does not then review) the state court's determination of an issue of state law. Habeas corpus jurisdiction, though in substance having many similarities to appellate review, technically involves a separate civil lawsuit (rather than an appeal from the state court's criminal case), in which additional evidence can be taken, and the scope of review of state court determinations, both of law and fact, has varied considerably from that typically provided on appeal. Finally, whether or not Justice Story's view of removal jurisdiction as appellate is deemed persuasive today, it seems easy enough to distinguish removal soon after a state court action is filed from the effort, in Rooker, to have a federal district court set aside a plenary adjudication by the state court system. Rooker may be wrong, but not because it is indistinguishable from the examples Amar gives. 
question this quotation raises is whether there is, or should be, a strong connection between two distinct issues, both of which implicate a question of parity between state and federal courts. The first is the constitutional question whether article III gives Congress unlimited power to restrict federal court jurisdiction, and to leave some cases within the federal judicial power (or within its "mandatory tier") to state court resolution. The second is the subconstitutional question whether particular jurisdictional statutes (for example, habeas corpus legislation, ${ }^{217}$ or section 1983 and its accompanying jurisdictional grant ${ }^{218}$ ) should be interpreted as calling for federal court adjudication in particular circumstances.

Amar's view that the questions are linked could be seen as another example of his preference for holistic explanation. Here, his approach extends beyond the interpretation of article III itself; he offers a holistic view of the field of federal jurisdiction-of constitutional and non-constitutional issues-premised on a single vision of disparity between state and federal courts. He described the "aim of [his initial article on article III as establishing] as a matter of constitutional law what Burt Neuborne has already argued persuasively as a matter of sociology: state judges do not enjoy parity with Article III judges."219 My own view is that, whatever the merits of the two-tier thesis, this broader holism is not particularly illuminating, and that discussions of federal jurisdiction should make more of an effort to separate the two questions of parity. ${ }^{220}$

The sub-constitutional doctrines that Amar criticizes-those restricting federal habeas corpus jurisdiction, or providing for federal court abstention-raise no constitutional question, for Supreme Court review of state court decisions is maintained. Indeed, Congress could, consistently with Amar's own thesis, eliminate federal habeas corpus jurisdiction over state convicts. ${ }^{221}$ Similarly, Congress, or the courts, could expand further the circumstances in which federal courts abstain in favor of state court adjudication. Thus, Amar's thesis has no bearing on whether the Supreme Court has cutback too far on federal habeas corpus jurisdiction, ${ }^{222}$ or whether

217 See 28 U.S.C. $\$ \S 2241-55$ (1982).

218 See 42 U.S.C. § 1983 (1982); 28 U.S.C. § 1343(a)(3) (1982).

219 Amar, Neo-Federalist View, supra note 1, at 238 n.115 (citing Neuborne, The Myth of Parity, 90 Harv. L. Rev. 1105 (1977)).

220 I have not always been sufficiently careful in this respect. See Meltzer, State Court Forfeitures of Federal Rights, 99 HARv. L. REv. 1128, 1231-34 (1986).

221 See HART \& WEChSLER, supra note 2, at 1577-78.

222 See generally id. at 1506-68; id. at 124-48 (Supp. 1989). 
Younger v. Harris ${ }^{223}$ was correctly decided or has been properly extended.

Of course, as Dick Fallon has argued, ${ }^{224}$ there may well be a connection between the ways that particular scholars or judges answer the distinct constitutional and sub-constitutional questions about the parity of state and federal courts. Those who believe that article III limits Congress's power to restrict federal court jurisdiction are more likely to aclvocate broad interpretation of habeas corpus jurisdiction or 42 U.S.C. $\S 1983$ while disfavoring abstention doctrines; those who believe Congress has unlimited jurisdictional power to restrict jurisdiction may be more likely to approve of limitations on the federal courts' exercise of statutory jurisdiction. Thus, one might believe that acceptance of Amar's thesis-and its premise that state courts are not, as a constitutional matter, adequate substitutes for article III courts--would make judges more reluctant to narrow federal jurisdiction.

I do not discount that possibility, but it still seems to me that Amar's effort to link the two questions is ultimately unhelpful. To begin with, the connection is not a necessary one. Martin Redish and Paul Bator, for example, share the traditionalist view of article III, ${ }^{225}$ but hold widely different views about the appropriate scope and interpretation of congressional grants of federal court jurisdiction. ${ }^{226}$

Moreover, the link that Amar tries to forge is not clearly desirable. For it is not only strong nationalists like Amar who might view the two issues as related. Aside from the dictum in Martin v. Hunter's Lessee, ${ }^{227}$ Supreme Court decisions almost uniformly suggest (also often in dictum) that Congress's power to restrict federal court jurisdiction is unlimited, ${ }^{228}$ and there is little reason to expect an about-

223401 U.S. $37,43-54$ (1971).

224 See Fallon, supra note 215, at 1251.

225 See Bator, supra note 2, at 1030; Redish, Power to Regulate, supra note 2, at 927.

226 Compare Bator, Some Thoughts on Applied Federalism, 6 HARv. J.L. \& PUB. PoL'y. 51 (1982), Bator, Finality in Criminal Law and Federal Habeas Corpus for State Prisoners, 76 HARV. L. REv. 441, 509 (1963) and Bator, supra note 66, at 622 n.49 with M. REDISH, Federal JuRisdiction: Tensions in the Allocation of Judicial Power 1-4, 337-73 (2d ed. 1989) and Redish, Constitutimal Limitations, supra note 5, at 143-61.

22714 U.S. (1 Wheat.) 304 (1\&i16).

228 See, e.g., Palmore v. United States, 411 U.S. 389, 400-02 (1973); Lockerty v. Phillips, 319 U.S. 182, 187 (1943); Kline v. Burke Construction Co., 260 U.S. 226, 234 (1922); Ex parte McCardle, 74 U.S. (7 Wall.) 506, 513-14 (1868); Cary v. Curtis, 44 U.S. (3 How.) 236, 245 (1845).

Amar's claim that major Marshall Court opinions support his thesis seems to me a bit strained. See Amar, supra note 6, at 1513 n.37. The passage he cites from 
face from the Supreme Court of the 1990s. Under Amar's holistic approach, a judge who believes Congress has unlimited power under article III to assign final adjudication of all cases to the state courts might also treat state and federal courts as equivalents when interpreting congressional grants of federal jurisdiction. Such an approach, I believe, would be not simply mistaken but potentially quite harmful.

Though surely a congressional grant of federal court jurisdiction should establish a strong "principle of preference" favoring its exercise, ${ }^{229}$ when hard questions of interpretation and application invariably arise, the invocation of disparity offers little guidance in resolving those questions. Indeed, so long as Supreme Court review of state courts exists, the very decision by Congress to grant any jurisdiction to the lower federal courts ordinarily rests on a belief in disparity. For if the federal courts did not promise something differ-

Osborn v. Bank of the United States, 22 U.S. (9 Wheat.) 738, 821-22 (1824), suggests that federal question jurisdiction was of particular importance, but does not suggest that it (much less the admiralty or ambassador jurisdiction) is mandatory. The passage from Cohens v. Virginia, 19 U.S. (6 Wheat.) 264, 378 (1821), merely classifies article III's heads of jurisdiction into two groups, those based on the character of the cause and those based on the character of the parties. There is no reference to the word "all," nor any suggestion that any portion of article III is mandatory.

For discussion of Amar's reliance on John Marshall's extra-judicial defense of McCulloch v. Maryland, 17 U.S. (4 Wheat) 400 (1819), see supra text accompanying notes 77-81.

From the Taney Court, Amar cites Rhode Island v. Massachusetts, 37 U.S. (12 Pet.) 657 (1838). See Amar, supra note 6, at 1513 n.37. There, counsel for Massachusetts (the defendant) contended that the Supreme Court was not obligated to exercise original jurisdiction, as article III's description of the jurisdiction over suits between states was not modified by the word "all." See Rhode Island, 37 U.S. (12 Pet.) at 672-73. Justice Baldwin acknowledged but gave little weight to counsel's suggestion: "[T]hough the constitution does not, in terms, extend the judicial power to all controversies between two or more states, yet it in terms excludes none, whatever may be their nature or subject." Id. at 721 .

Baldwin proceeded to discuss the Supreme Court's original jurisdiction, and then observed that Congress may distribute the "residue" between the Supreme Court and the inferior courts, "which it was bound to ordain and establish." Id. The language could (but need not) be read to suggest that the judicial power must be vested in some federal court, but Baldwin does not distinguish between Amar's two tiers. And this ambiguous dictum seems particularly weak support for Amar in view of Baldwin's fundamentally mistaken belief that Congress must establish inferior federal courts.

Amar chooses his words carefully when he says, in his reply, that none of these cases "in any way criticizes or challenges" the mandatory/permissive distinction articulated in Martin. Amar, Reply, supra note 9, at 1666. As phrased, the point is correct. It is also true, however, that these cases do not endorse or even acknowledge a mandatory/permissive distinction.

229 See Shapiro, supra note 216, at 547 (quoting Friendly, Indiscretion About Discretion, 31 EMORY L.J. 747, 768 (1982)). 
ent from (and preferable to) state court adjudication, there would be little point in creating the added complexity that dual systems of jurisdiction entail. ${ }^{230}$ But it hardly follows from that observation that whenever a difficult jurisdictional question is presented, the right answer is that federal court jurisdiction should be exercised. Rather, in resolving such questions, context matters, both temporal and procedural. I will offer two brief illustrations.

The first compares the federal courts' role in constitutional litigation before 1937 with their role since 1954 . It may be that lower federal court judges embraced the Supreme Court's substantive due process decisions of the early 1900s more enthusiastically than did their state court counterparts. Certainly that perception ${ }^{231}$ influenced the enactment of the Norris LaGuardia Act, ${ }^{232}$ the Johnson Act of $1934,{ }^{233}$ and the Tax Injunction Act of $1937 .{ }^{234}$ Only the first of these statutes even arguably would raise a constitutional question under Amar's thesis, ${ }^{235}$ but Congress might well have thought, as a matter of subconstitutional policy, that state court decisionmaking in these areas was preferable to federal court decisionmaking. Given that background, the Supreme Court may have thought it appropriate to narrowly construe federal jurisdiction over these matters. ${ }^{236}$ By contrast, I think it doubtful that Brown v. Board of Education ${ }^{237}$ could have been meaningfully enforced had Congress restricted the availability of lower federal court jurisdiction over school desegregation suits. Here, too, Congress (and the courts) might have thought disparity to be considerable, but in this case to call for the very broad

230 There is one other possible reason for federal court jurisdiction: a belief that a dual system may lead to a healthy competition between state and federal judges. I doubt that most grants of federal jurisdiction, and in particular the federal question jurisdiction, rest primarily on that premise.

231 See, e.g., F. Frankfurter \& N. Greene, The Labor Injunction 212-20 (1930); Gunther, supra note 2, at 919-20; see also S. REP. No. 125, 73d Cong., 1st Sess. 4-5, 8-9 (1933) (Johnson Act); S. REp. No. 1035, 75th Cong., 1st Sess. 1-2 (1937) (Tax Injunction Act modeled on Johnson Act).

23247 Stat. 70 (1932) (codified as amended at 29 U.S.C. $\$ \S 101-15$ (1982 \& Supp. V 1987)).

23348 Stat. 775 (codified at 23 U.S.C. § 1342 (1982)).

23450 Stat. 738 (codified as amended at 28 U.S.C. $\$ 1341$ (1982)).

235 See supra note 211 and accompanying text.

236 See, e.g., Great Lakes Dredge \& Dock Co. v. Huffman, 319 U.S. 293, 298-301 (1943) (under principles of comity, federal court should not issue declaratory judgment, whose practical effect would be the same as a prohibited injunction, where state remedies are adequate); California v. Grace Brethren Church, 457 U.S. 393, 407-19 (1982) (interpreting the Tax Injunction Act itself as barring such relief).

237347 U.S. 483 (1954). 
exercise of federal jurisdiction. ${ }^{238}$ Thus, the mere invocation of disparity does not provide a satisfactory guide for Congress or the courts.

My second example is more specific, relating to the Younger doctrine. In my view, a defendant in a pending state court criminal proceeding should not be barred from obtaining federal interlocutory relief from additional future prosecutions, providing, of course, that the requisites for an interlocutory injunction are satisfied. This form of prospective relief promotes extremely important policies, is not available in the state prosecution itself, and can (though need not) be tailored to limit interference with state court proceedings. ${ }^{239}$ Thus, I think the Court erred in Doran v. Salem Inn, Inc. ${ }^{240}$ in declining, in such a case, to exercise the presumptively available federal court jurisdiction over civil rights actions under 42 U.S.C. § 1983.

By contrast, I think it would be a mistake for a federal district court to exercise jurisdiction over a civil rights action in which a defendant in a pending state prosecution raised federal constitutional objections to the grand jury's racial composition, to the jury instructions on burden of proof, or to the introduction of particular evidence. The availability of such relief is far more intrusive, particularly given the number of constitutional issues that can arise in a criminal trial, and state court resolution of those issues provides adequate relief for constitutional violations. Thus, I approve of the Court's decisions limiting federal jurisdiction in such cases, ${ }^{241}$ even

238 Indeed, some important decisions broadly construing federal court jurisdiction occurred in this context. See, e.g., Milliken v. Bradley, 433 U.S. 267, 289 (1977) (broadly construing the scope of permissible "prospective injunctive relief" under the eleventh amendment); McNeese v. Board of Educ., 373 U.S. 668, 671 (1963) (refusing to require exhaustion of state administrative remedies before resort to federal court under 42 U.S.C. $\$ 1983$ ); f. Mayor of Philadelphia v. Educational Equality League, 415 U.S. 605, 628 (1974) (abstention disfavored in equal protection suits). In addition, other cases broadly expanded the scope of federal equity jurisdiction, both in approving structural injunctions to desegregate school systems, see, e.g., Swann v. Charlotte-Mecklenburg Board of Educ., 402 U.S. 1, 17 (1971), and in other respects, see, e.g., United States v. Hall, 472 F.2d 261, 262 (5th Cir. 1972); Griffin v. County School Bd., 363 F.2d 206, 212 (4th Cir. 1966), cert. denied, 385 U.S. 960 (1966).

239 For arguments supporting that position, see HART \& WECHSLER, supra note 2, at 1420-24; Laycock, Federal Interference with State Prosecutions: The Need for Prospective Relief, 1977 Sup. Cr. REv. 193, 202-14.

240422 U.S. 922 (1975).

241 See, e.g., Cleary v. Bolger, 371 U.S. 392 (1963); Stefanelli v. Minard, 342 U.S. 117 (1951). I should add that my position is not premised on the possible availability, after the conclusion of state court proceedings, of federal habeas corpus relief, and that in some instances habeas relief may in fact not be available. See, e.g., Teague v. Lane, 109 S. Ct. 1060, 1077-78 (1989) (ordinarily no habeas relief for 
assuming (as I do) that federal courts were, and still are, on average, more receptive than state courts to claims of federal constitutional right. ${ }^{242}$

There is no reason to think that state and federal courts are on more of a par in the second situation than the first. The point is, simply, that general propositions about parity do not decide concrete cases.

"novel" constitutional claims); Stone v. Powell, 428 U.S. 465, 481-82 (1976) (ordinarily no habeas relief for fourth amendment claims); 28 U.S.C. $\$ 2241$ (c) (1982) (habeas petitioner must be in custody).

242 See Meltzer, supra note 220, at 1231-33; see also Meltzer, The Judiciary's Bicentennial, 56 U. CHI. L. REv. 423, 425-6 (1989).

For general discussion of "parity," see Chemerinsky, Parity Reconsidered: Defining a Role for the Federal Judiciary, 36 UCLA L. REv. 233, 236 (1988) (calling the parity debate unresolvable because it is an empirical question without an empirical answer); Neuborne, supra note 219, at 1105 (arguing that "the assumption of parity is, at best, a dangerous myth"); Solimine \& Walker, Constitutional Litigation in Federal and State Courts: An Empirical Analysis of Judicial Parity, 10 HASTings Const. L.Q. 213, 214-15 (1983) (arguing that state courts are not hostile to federal claims and that parity does exist); Solimine \& Walker, State Court Protection of Federal Constitutional Rights, 12 Harv. J.L. \& Pub. PoL'y 127 (1989); see also Wells, Is Disparity a Problem, 22 GA. L. Rev. 283, $301,335-6$ (1988) (suggesting that state courts are less likely than federal courts to uphold claims of individual right, but that difference in performance does not always justify arguments for federal jurisdiction). 